\title{
Asymmetric Catalysis. Asymmetric Catalytic Intramolecular Hydroacylation of 4-Pentenals Using Chiral Rhodium Diphosphine Catalysts
}

\author{
Richard W. Barnhart, Xianqi Wang, Pedro Noheda, Steven H. Bergens, \\ John Whelan, and B. Bosnich* \\ Contribution from the Department of Chemistry, The University of Chicago, 5735 South Ellis \\ Avenue, Chicago, Illinois 60637
}

Received November 1, $1993^{\circ}$

\begin{abstract}
Catalysts of the type [Rh(chiral diphosphine)]+ convert 4-substituted 4-pentenals into the corresponding 3-substituted cyclopentanones with generally high turnover numbers and frequencies at $25^{\circ} \mathrm{C}$. The enantioselectivities of various substituted 4-pentenals with two chiral diphosphines have been explored. It was found that with the binap catalyst, almost complete enantioselectivity is observed for 4-pentenal substrates bearing 4-substituted tertiary substituents and for ester groups. Ketonic substituents give very high enantioselectivities. The mechanism of intramolecular hydroacylation has been explored, and it is suggested that an important consideration for obtaining high turnover frequencies is related to the acyl-alkyl reductive elimination mechanism which is inferred to occur by a process similar to ester hydrolysis. The origin of the enantioselection is discussed in terms of the interactions between the phenyl groups of the phosphine and the substituent of the pentenal.
\end{abstract}

Intramolecular hydroacylation is one of the more attractive catalytic processes because it converts a pentenal to a cyclic ketone (eq 1). The process is unusual in that the events leading to the

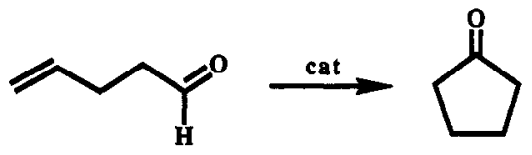

product appear to involve scission of the acyl-hydrogen bond to give a hydrido-acyl intermediate followed by the addition of the two fragments to the double bond. With rhodium-based catalysts, 5-membered ring products are almost always produced.

The discovery of Tsuji ${ }^{1}$ that Wilkinson's catalyst, $\left[\mathrm{Rh}\left(\mathrm{PPh}_{3_{3}}\right)_{3^{-}}\right.$ $\mathrm{Cl}$, was capable of decarbonylating aldehydes to form the alkane and the carbonylated complex, trans-[Rh($\left.\left(\mathrm{PPh}_{3}\right)_{2}(\mathrm{CO}) \mathrm{Cl}\right]$, suggested that oxidative addition across the acyl-hydrogen bond was a step in the decarbonylation. Such a hydrido-acyl intermediate could, in principle, hydroacylate a double bond, provided that the rate of hydroacylation was faster than the decarbonylation rate.

The first example of intramolecular hydroacylation of 4-pentenals was reported by Sakai, ${ }^{2}$ who used Wilkinson's catalyst. Stoichiometric amounts of $\left[\mathrm{Rh}\left(\mathrm{PPh}_{3}\right)_{3} \mathrm{Cl}\right]$ and the pentenal were used, and only a $30 \%$ yield of the desired cyclopentanone was obtained. The remainder of the material was composed of decarbonylation products. Subsequently, Miller ${ }^{3}$ showed that the $\left[\mathrm{Rh}\left(\mathrm{PPh}_{3}\right)_{3} \mathrm{Cl}\right]$ complex could act as a catalyst under ethylene pressure, and Larock ${ }^{4}$ explored the catalysis with a variety of substrates and with catalysts incorporating differently substituted unidentate triarylphosphines. In neither study were more than a few turnovers observed before all of the catalyst was converted

- Abstract published in Advance ACS Abstracts, February 1, 1994.

(1) Tsuji, J.; Ohno, K. Tetrahedron Lett. 1965, 3669.

(2) Sakai, K.; Ide, J.; Oda, O.; Nakamure, N. Tetrahedron Lett. 1972, 1287.

(3) Lochow, C. F; Miller, R. G. J. Am. Chem. Soc. 1976, 98, 1281. Campbell, R. E., Jr.; Lochow, C. F.; Vora, K. P.; Miller, R. G. J. Am. Chem. Soc. 1980, 102, 5824 . Campbell, R. E., Jr.; Miller, R. G. J. Organomet. Chem. 1980, 186, C27. Vora, K.P.; Lochow, C. F.; Miller, R. G.J. Organomet. Chem. 1980, 192, 257. 190.

(4) Larock, R. C.; Oertle, K.; Potter, G. F. J. Am. Chem. Soc. 1980, 102,

$0002-7863 / 94 / 1516-1821 \$ 04.50 / 0$ to the catalytically inactive trans- $\left[\mathrm{Rh}_{(}\left(\mathrm{PAr}_{3}\right)_{2}(\mathrm{CO}) \mathrm{Cl}\right](\mathrm{Ar}=$ aryl group) complex arising from competing decarbonylation. Intermolecular hydroacylation has been achieved under olefin pressure and usually at high temperatures using rhodium ${ }^{5}$ and ruthenium ${ }^{6}$ catalysts.

We recently reported, ${ }^{7,8}$ that cationic complexes of the type $\left[\mathrm{Rh} \text { (diphosphine)(solvent) }{ }_{2}\right]^{+}$were efficient catalysts for the intramolecular hydroacylation of 4-pentenals. High turnover rates were observed, and turnover numbers of the order 500 could be achieved before decarbonylation significantly reduced the turnover rate. It was argued that the characteristics which favored the catalytic efficiency of these cationic rhodium(I) complexes bearing one chelating diphosphine ligand over the neutral complexes derived from Wilkinson's catalyst were the following. First, provided that the solvent molecules are weakly bound in the $\left[\mathrm{Rh} \text { (diphosphine)(solvent) }{ }_{2}\right]^{+}$catalysts, the 6 -coordinate rhodium(III) species that is formed after oxidative addition of the acyl-hydrogen bond will have two coordination positions available, thus allowing for coordination of the olefin as illustrated in 1. The presence of virtual coordination unsaturation in both<smiles>[R2][R]1([H])CCCC(=O)C1</smiles>

the rhodium(I) and the rhodium(III) states is expected to accelerate catalysis' since slow ligand dissociation will not impede the catalytic steps. Second, because of the positive charge and the presence of cis-disposed phosphines, carbonyl complexes of the type $[\mathrm{Rh} \text { (diphosphine)(CO) }]^{+}(n=1$ or 2$)$ are expected to be much less stable than the neutral, transdisposed phosphine complexes, trans- $\left[\mathrm{Rh}_{(}\left(\mathrm{PAr}_{3}\right)_{2}(\mathrm{CO}) \mathrm{Cl}\right]$, that are derived from the previous catalysts.

(5) Marder, T. B.; Roe, C.; Milstein, D. Organometallics 1988, 7, 1451.

(6) Kondo, T.; Tsuji, Y.; Watanabe, Y. Tetrahedron Lett. 1987, 28, 6229. Kondo, T.; Akazome, M.; Tsuji, Y.; Watanabe, Y. J. Org. Chem. 1990, 55, 1286.

(7) Fairlie, D. P.; Bosnich, B. Organometallics 1988, 7, 936.

(8) Fairlie, D. P.; Bosnich, B. Organometallics 1988, 7, 946.

(9) Milstein, D. J. Chem. Soc., Chem. Commun. 1982, 1357. 
Scheme 1
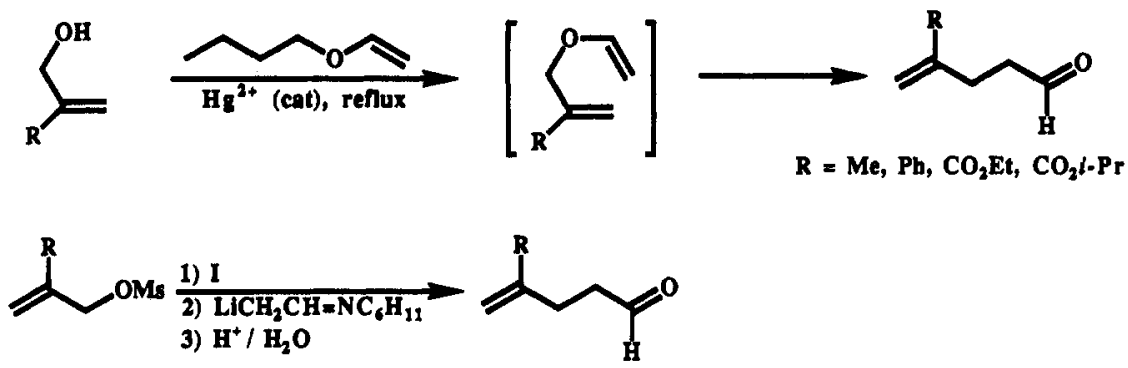

$\mathbf{R}=\mathbf{M e}, \boldsymbol{t} \cdot \mathbf{B u}, \mathbf{P h}$

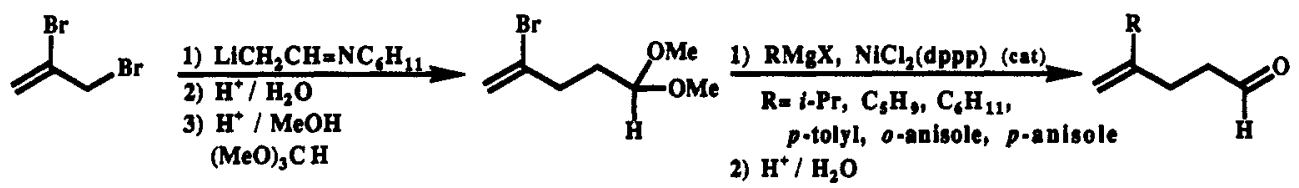

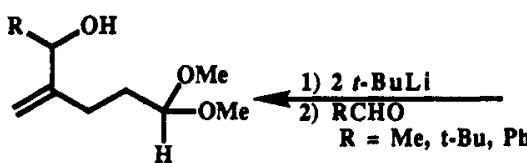

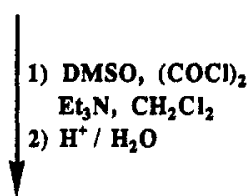<smiles>[R]C(=O)C(=C)CCC=O</smiles>

Thus we expect that decarbonylation with these cationic complexes will be suppressed, at least thermodynamically.

1. Asymmetric Intramolecular Hydroacylation. The first asymmetric transformation was reported by James, ${ }^{10}$ who used bis-chiral diphosphinerhodium(I) complexes for the kinetic resolution of racemic mixtures of chiral 4-pentenals. Good enantioselectivity was observed despite the elevated temperatures used. While the present work was in progress, Sakai ${ }^{11}$ reported good to excellent enantioselectivities using [Rh(chiral diphosphine) $]^{+}$catalysts for the conversion of prochiral 4-pentenals to chiral cyclopentanones.

This paper describes our exploration of the enantioselectivity provided by two $\left[\mathrm{Rh} \text { (chiral diphosphine)(solvent) }{ }_{2}\right]^{+}$catalysts for the conversion of 4-substituted 4-pentenals to chiral 3-cyclopentanones (eq 2). Although a variety of chiral diphosphines<smiles>[R]C(=C)CCC(=O)CC(C)CCC</smiles>

were examined, we concentrated most of our attention on the ligands $(S, S)$-chiraphos ${ }^{12}(2)$ and $(S)$-binap ${ }^{13}(3)$, and the latter

(10) James, B. R.; Young, C. G. J. Chem. Soc., Chem. Commun. 1983, 1215. James, B. R.; Young, C. G. J. Organomet. Chem. 1985, 285, 321.

(1i) Taura, Y.; Tanaka, M.; Funakoshi, K.; Sakai, K. Tetrahedron Lett. 1989, 30, 6349. Taura, Y.; Tanaka, M.; Wu, X. M.; Funakoshi, K.; Sakai, K. Tetrahedron 1991, 47, 4879. Wu, X. M.; Funakoshi, K.; Sakai, K Tetrahedron Lett. 1992, 33, 6331.

(12) Fryzuk, M. D.; Bosnich, B. J. Am. Chem. Soc. 1977, 99, 6262.

proved to be exceptionally effective for certain classes of substrates. As noted previously, ${ }^{7}$ 5-substituted pentenals react slowly or not at all with the present catalysts.<smiles>C[C@H](Pc1ccccc1)[C@H](C)c1ccccc1</smiles>

2

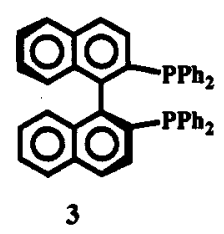

2. Catalysis. The 4-pentenals were prepared mainly by four general methods (Scheme 1). The first was the $\mathrm{Hg}^{2+}$-catalyzed vinylation of 2-substituted allyl alcohols followed by Claissen rearrangement. ${ }^{14}$ The second involved 2-carbon homologation of 2-substituted allyl alcohols by 2-lithioethylidenecyclohexylamine followed by acid hydrolysis. ${ }^{15}$ The third method involved nickel-catalyzed crosscoupling ${ }^{16}$ between 4 -bromo-4-pentenal dimethyl acetal and Grignard reagents, followed by acid hydrolysis. The fourth method involved the reactions of 4-lithio4-pentenal dimethyl acetal ${ }^{17}$ with the electrophiles, aldehydes, ketones, or monochlorosilanes. The carbinol products from aldehydes were oxidized (Swern) to the ketone, and those from ketones were methylated to the ether. Acid hydrolysis gave the

(13) Miyashita, A.; Yasuda, A.; Takya, H.; Toriumi, K.; Ito, T.; Sauchi, T.; Noyori, R. J. Am. Chem. Soc. 1980, 102, 7932

(14) Watanabe, W. H.; Conlon, L. E. J. Am. Chem. Soc. 1957, 79, 2828. Montgomery, L. K.; Matt, J. W. J. Am. Chem. Soc. 1967, 89, 6556.

(15) Le Borgne, J. F. J. Organomet. Chem. 1976, 122, 129.

(16) Kumada, M. Pure Appl. Chem. 1980, 52, 669.

(17) Miller, R. B.; McGarvey, G. Synth. Commun. 1979, 9, 831. 
Table 1. Asymmetric Catalytic Intramolecular Hydroacylation of 4-Pentenals Using [Rh(diphosphine)]ClO ${ }_{4}$ Catalysts

\begin{tabular}{|c|c|c|c|c|}
\hline entry & substrate & $(S, S)$-chiraphos ee, $\%$ (config) & $(S)$-binap ${ }^{b}$ ee, \% (config) & product \\
\hline 1 & & $42(S)$ & $78(S)$ & \\
\hline 2 & & $45(S)$ & $60(S)^{c}$ & \\
\hline 3 & & $41(S)$ & $81(S)$ & \\
\hline 4 & & $50(S)$ & $69(S)^{c}$ & \\
\hline 5 & & $78(S)$ & $70(S)$ & \\
\hline 6 & & $72(S)$ & $44(S)$ & \\
\hline 7 & & $75(S)$ & $25(S)$ & \\
\hline 8 & & $65(S)$ & $17(S)^{a}$ & \\
\hline
\end{tabular}

a Catalysis in $\mathrm{CH}_{2} \mathrm{Cl}_{2}$ at $25^{\circ} \mathrm{C}$ using $\sim 4 \mathrm{~mol} \% \mathrm{Rh} .{ }^{b}$ Catalysis in acetone at $25^{\circ} \mathrm{C}$ using $\sim 4 \mathrm{~mol} \% \mathrm{Rh} .{ }^{c}$ See ref 11 .

desired pentenal. Although these methods are efficient, acid hydrolysis of the acetals is sensitive and requires precise conditions. These are provided in the Experimental Section. It is important to note that even small amounts of acid in the substrate will deactivate the catalysts, and generally the pentenals were flash chromatographed before use.

The enantioselectivities of the cyclopentanone products were determined by ${ }^{13} \mathrm{C}$ NMR of the hydrazones 4 formed with the optically active hydrazine ${ }^{18} 5$. Roughly equal proportions of the

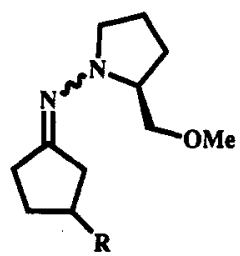<smiles>COC[C@@H]1CCCN1N</smiles>

SAMP

$\mathbf{5}$ syn and anti isomers of 4 were formed in all cases, except the bis-hydrazone of 3-acetylcyclopentanone. The ${ }^{13} \mathrm{C}$ NMR signals for the imine carbons of the diastereomers 4 were well-separated singlets, a pair for each geometric isomer. With sufficient acquisition time and appropriate pulse delay $(5 \mathrm{~s})$, enantiomeric excesses (ees) were determined to within $1 \%$. The assignments of the major and minor isomer signal positions (Table 4) were confirmed by the signals observed for racemic samples of 4 , prepared from the achiral catalyst derived from the diphos $\left(\mathrm{Ph}_{2}-\right.$ $\mathrm{PCH}_{2} \mathrm{CH}_{2} \mathrm{PPh}_{2}$ ) ligand. The absolute configurations of the cyclopentanone products were established from the optical rotations compared to those reported for molecules of known configuration (Table 5). Not all of the cyclopentanones syn-

(18) Enders, D.; Eichenauer, H. Tetrahedron Lett. 1977, 191. thesized here are of known absolute configurations, however, and we have made assignments based on the chemical shifts of the ${ }^{13} \mathrm{C}$ NMR imine carbon signals of 4 . Thus we found that the hydrazone 4 of the $(S)$-cyclopentanone enantiomer of established absolute configuration always gave a ${ }^{13} \mathrm{C}$ NMR imine carbon signal upfield from the hydrazone of the $R$ enantiomer. Assignments were made on this assumption for all of the products of unknown configuration.

Catalysis was performed in methylene chloride or acetone solutions at $25^{\circ} \mathrm{C}$. A variety of chiral diphosphines were explored initially, but we found that the binap catalysts generally gave the highest ees. The chiraphos catalyst results are included for comparison. The chiraphos catalyst precursor used was the crystalline aryl-bridged dimer, $[\mathrm{Rh}(S, S)$-chiraphos $)]_{2}\left(\mathrm{ClO}_{4}\right)_{2}{ }^{7}$ The $\left[\mathrm{Rh}(S)\right.$-binap)(solvent) $\left.{ }_{2}\right] \mathrm{ClO}_{4}$ catalyst was prepared in situ by hydrogenation of the crystalline $[\mathrm{Rh}((S)$-binap $)(\mathrm{NBD})] \mathrm{ClO}_{4}{ }^{13}$ (NBD = norbornadiene) complex. Generally, $4 \mathrm{~mol} \%$ catalyst loadings were used, but much lower concentrations suffice for systems which are not sterically hindered. Catalysis was complete within $2 \mathrm{~h}$ for most substrates listed here. Chemical yields were $>95 \%$, and isolated yields were about $90 \%$. Thus very little decarbonylation of the substrates occurred.

The ees for various substrates are listed in Tables 1,2, and 3 . Table 1 illustrates the variation in ee with some aliphatic and aryl substituents. All of the prevailing enantiomers have the same $(S)$ absolute configuration with either $(S)$-phosphine catalyst. The ees range from modest to good. For aliphatic substituents (entries 1-4), the binap catalyst gives higher ees than does the chiraphos catalyst, whereas the reverse obtains with aryl substituents.

Table 2 lists substrates bearing a tertiary substituent which illustrate two remarkable trends. The prevailing product enantiomer for the $(S, S)$-chiraphos catalyst is opposite that for the 
Table 2. Asymmetric Catalytic Intramolecular Hydroacylation of 4-Pentenals Using [Rh(diphosphine)]ClO 4 Catalysts

entry

a Catalysis in $\mathrm{CH}_{2} \mathrm{Cl}_{2}$ at $25^{\circ} \mathrm{C}$ using $\sim 4 \mathrm{~mol} \% \mathrm{Rh}$. ${ }^{b}$ See ref 11 .

Table 3. Asymmetric Catalytic Intramolecular Hydroacylation of 4-Pentenals Using [Rh(diphosphine) $] \mathrm{ClO}_{4}$ Catalysts

\begin{tabular}{|c|c|c|c|c|}
\hline entry & substrate & $(S, S)$-chiraphos ${ }^{a}$ ee, $\%$ (config) & $(S)$-binap ee, $\%$ (config) & product \\
\hline 15 & & $13(R)$ & $87(S)^{a}$ & \\
\hline 16 & & $64(R)$ & $94(S)^{2}$ & \\
\hline 17 & & $63(R)$ & $94(S)^{a}$ & \\
\hline 18 & & $35(S)$ & $>99(S)^{6}$ & \\
\hline 19 & & $11(R)$ & $>99(S)^{b}$ & \\
\hline
\end{tabular}

a Catalysis in $\mathrm{CH}_{2} \mathrm{Cl}_{2}$ at $25^{\circ} \mathrm{C}$ using $\sim 4 \mathrm{~mol} \% \mathrm{Rh} .{ }^{b}$ Catalysis in acetone at $25^{\circ} \mathrm{C}$ using $\sim 4 \mathrm{~mol} \% \mathrm{Rh}$.

(S)-binap catalyst. Further, whereas the ees observed for the chiraphos catalyst are low, those observed for the binap catalyst

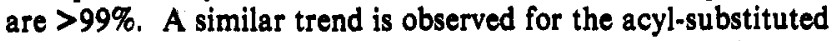
substrates in Table 3. Except for entry 18, the prevailing $R$ configuration is observed for the $(S, S)$-chiraphos catalyst, whereas the opposite configuration predominates for $(S)$-binap. Further, the ees for the binap catalyst are very high. The $\alpha$-carbonyl group $(\mathrm{C}=0$ ) seems to be the major factor in obtaining high ees for the ketonic substrates (entries 15, 16, and 17), and the ketonic $R$ groups have only a slight effect on the ee. The same is true for ester substituents. Thus it appears that there are two classes of substrates which will give high ees with the binap catalyst; those with tertiary substituents and those with acyl substituents at the 4-pentenal position.

We found that in $\mathrm{CD}_{2} \mathrm{Cl}_{2}$ solutions with the binap catalyst, the rate of catalysis depended on both the concentration of the catalyst and the number of turnovers that had occurred. The concentration of substrate for the catalyses reported in Tables 1, 2, and 3 was about $0.16 \mathrm{M}$. The concentration and turnover number effect on the turnover frequency was investigated using the substrate shown in entry 9 (Table 2). It was found that the rate of catalysis increased as the substrate concentration increased to $0.4 \mathrm{M}$ in $\mathrm{CD}_{2} \mathrm{Cl}_{2}$ solutions at $25^{\circ} \mathrm{C}$ for catalyst concentrations of $0.8 \times$ $10^{-3}$ and $1.6 \times 10^{-3} \mathrm{M}$. Further increase in concentration of the substrate caused the rate to decrease. The increase in rate up to $0.4 \mathrm{M}$ substrate concentration presumably reflects increased productive binding of the substrate to the catalyst. The substrate inhibition observed at higher substrate concentrations probably reflects unproductive binding of the substrate. We noted these effects in earlier works. 7,8 The nature of the various catalystsubstrate adducts responsible for this behavior is unknown. NMR spectroscopy failed to identify the possible species because of the high substrate and very low catalyst concentrations and the rapid equilibration of the adducts. With respect to the turnover number effect on the rate, we found, for example, that at $0.8 \times 10^{-3} \mathrm{M}$ catalyst and $0.4 \mathrm{M}$ substrate, 450 turnovers ( $\sim 90 \%$ reaction) were observed in $16 \mathrm{~h}$. It took another $48 \mathrm{~h}$ to complete the last $10 \%$ of the reaction. Although a substrate concentration effect may play a part in the tailing off of turnover frequency, it is likely that much of the diminution in rate is caused by decarbonylation of the substrate. ${ }^{7,8}$ As a practical matter, the maximum efficiency of the catalysis, as defined by the trade-off between turnover 
Table 4. ${ }^{13} \mathrm{C}$ NMR Data of Diastereomeric Hydrazone Derivatives

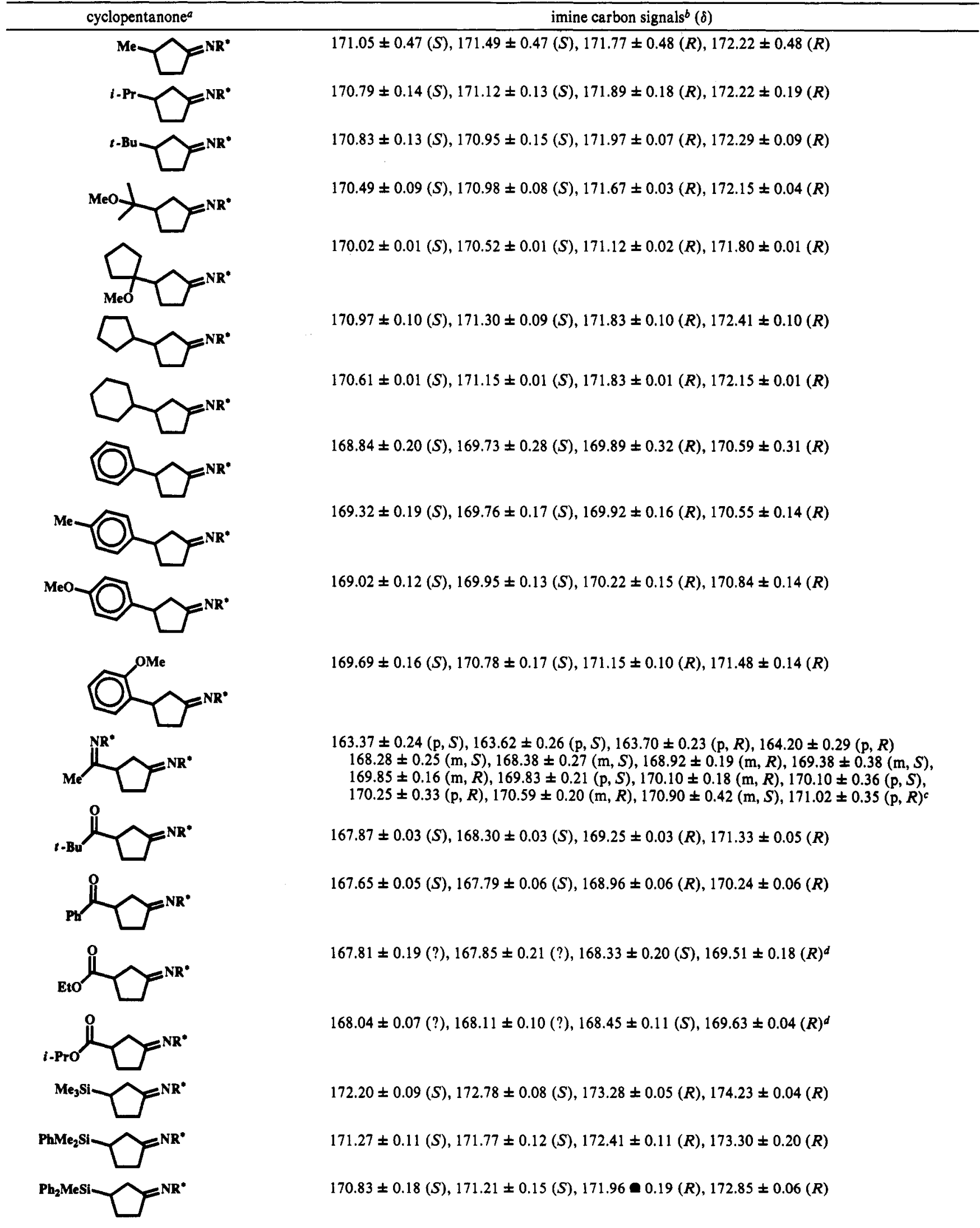

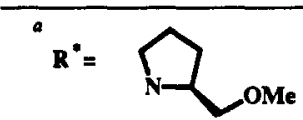

${ }^{b}$ All ${ }^{13} \mathrm{C}$ NMR data determined using $\mathrm{CDCl}_{3}$ solvent. $S$ amd $R$ denote absolute configuration. ${ }^{c} \mathrm{p}$ and $\mathrm{m}$ denote principle and minor diastereomers since the syn and anti isomers of the bis-hydrazones are not formed in equal amounts. ${ }^{d}$ Two upfield peaks sometimes coalesce. 
Table 5. Optical Rotations of Cyclopentanone Products ${ }^{a}$

\begin{tabular}{|c|c|c|c|}
\hline product & found $[\alpha]_{D^{R T}}$ & $\begin{array}{c}\text { calcd } \\
{[\alpha]_{D} \text { for }} \\
100 \% \mathrm{ee}^{b}\end{array}$ & $\begin{array}{c}\text { lit. }[\alpha]_{D} \\
\text { for } 100 \% \\
\text { ee (absolute } \\
\text { configuration) }\end{array}$ \\
\hline & $\begin{array}{l}-126^{\circ} \\
\left(c 0.99, \mathrm{CHCl}_{3}\right)\end{array}$ & $-161^{\circ}$ & $\begin{array}{l}+154.8^{\circ}(R) \\
\left(c 0.73, \mathrm{CHCl}_{3}\right)^{38}\end{array}$ \\
\hline & $\begin{array}{l}-110^{\circ} \\
\left(c 1.0, \mathrm{CHCl}_{3}\right)\end{array}$ & $-183^{\circ}$ & $\begin{array}{l}+186^{\circ}(R) \\
\left(\mathrm{CHCl}_{3}\right)^{39}\end{array}$ \\
\hline & $\begin{array}{l}-67.7^{\circ} \\
\left(c 1.0, \mathrm{CHCl}_{3}\right)\end{array}$ & $-86.8^{\circ}$ & $-87.6^{\circ}(S)^{40}$ \\
\hline & $\begin{array}{l}-22.2^{\circ} \\
(c 1.0, \mathrm{MeOH})\end{array}$ & $-22.2^{\circ}$ & $\begin{array}{l}-21.9^{\circ}(S) \\
(c 1.6, \mathrm{MeOH})^{41}\end{array}$ \\
\hline & $\begin{array}{l}-17.8^{\circ} \\
(c 1.0, \text { acetone })\end{array}$ & $-17.8^{\circ}$ & $\begin{array}{l}-15.9^{\circ}(S) \\
(c 1.7, \text { acetone })^{42}\end{array}$ \\
\hline (S) & $\begin{array}{l}-176^{\circ} \\
\left(c 1.0, \mathrm{CHCl}_{3}\right)\end{array}$ & $-176^{\circ}$ & $\begin{array}{l}-174.5 \text { to }-183^{\circ}(S) \\
\left(c 0.45, \mathrm{CHCl}_{3}\right)^{43}\end{array}$ \\
\hline
\end{tabular}

${ }^{a}$ Using $[\mathrm{Rh}((S)$-binap $)] \mathrm{ClO}_{4}$ catalyst. ${ }^{b}$ Calculated, $[\alpha]_{\mathrm{D}}=($ found $[\alpha]_{D} /$ (ee measured by diastereomeric hydrazone).

Scheme 2<smiles>[2H]C(=O)CCC=C</smiles><smiles>C=CCCCCCCCC</smiles>

C

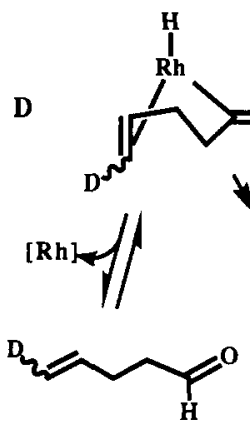

$\mathbf{E}$<smiles>O=C1CCCC1P</smiles><smiles>[2H]C([2H])C(C)CC</smiles><smiles>[2H]C1CC(CC)CCC1=O</smiles>

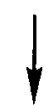<smiles>CCCC1CCCCC1=O</smiles>

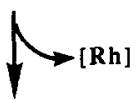<smiles>O=C1CCC(O)C1</smiles>

H these conditions, between 200 and 250 turnovers can be achieved rapidly before decarbonylation slows the catalysis.

3. Mechanism. Our previous work ${ }^{8}$ on catalytic hydroacylation using these types of catalysts suggests that the major steps in the process are those depicted in Scheme 2. The various intermediates depicted in Scheme 2 were inferred from the scrambling of the deuterium atom of substrate $\mathbf{A}$. Thus the process $\mathbf{A} \rightarrow \mathbf{B} \rightarrow \mathbf{C}$ $\rightarrow \mathbf{D} \rightarrow \mathbf{E}$ leads to transfer of the acyl deuterium to the cis and trans terminal positions of the double bond $(\mathbf{E})$. The deuterium
Scheme 3
$\mathbf{S}$

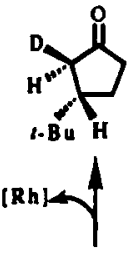

$\mathbf{R}$<smiles>[2H][C@@H]1C(=O)CC[C@]1([10CH3])[18OH]</smiles>

L

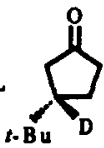

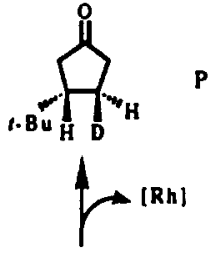<smiles>[2H][C@@H]1CC(=O)C[C@]1(C)[18OH]</smiles>

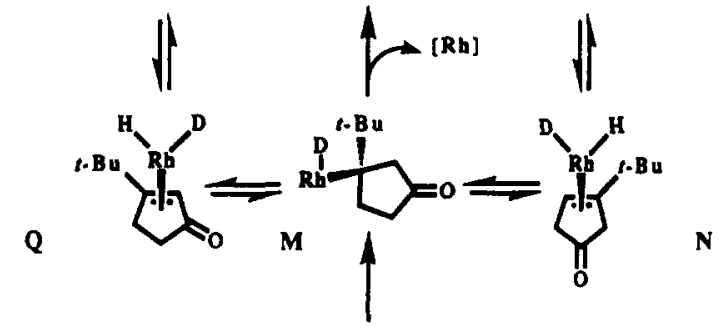

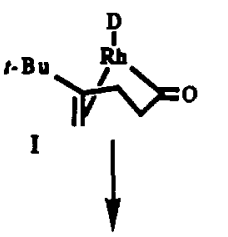

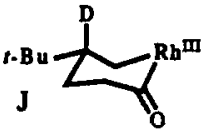<smiles>CCCCCC1CC1C1CC1CCC</smiles>

$\mathbf{K}$<smiles>[R9][C@@]1([13CH2])CCC2(C1)OO2</smiles>

scrambling observed in these catalytically unproductive steps indicates that all of the reversible steps $(A \rightleftarrows B \rightleftarrows C \rightleftarrows D \rightleftarrows E$ ) are rapid on the time scale of catalysis. Substantial amounts of $\mathrm{E}$ are observed during catalysis, and similar amounts of the $\alpha$ and $\beta$-deuterated cyclopentanones, $\mathbf{F}$ and $\mathbf{H}$, are observed at the end of the reaction. Other deuterium scrambling is observed with the chiraphos catalyst, but these findings are probably not relevant to the present discussion. These previous experiments were inferentially mute on how $B$ proceeded to $H$. It was assumed that $\mathbf{G}$ was formed.

We have attempted to obtain information about these steps for the asymmetric catalysis by using the substrate 6 with the $(S)$ binap catalyst in $\mathrm{CD}_{2} \mathrm{Cl}_{2}$ solutions at $25^{\circ} \mathrm{C}$ (analogous to Table 2 , entry 9). We have considered a number of possible paths for the process $B \rightarrow \mathbf{H}$. These are outlined in Scheme 3 using substrate 6.<smiles>C=C(CCCC)CCCC(=O)c1ccccc1</smiles>

The intermediate I can convert to $\mathbf{J}$ by olefin-deuterium insertion. The metallocycle $\mathbf{J}$ can generate the product $\mathbf{L}$ either by the conventional carbon-carbon reductive elimination process $(\mathbf{J} \rightarrow \mathbf{L})$ or by attack on the acyl carbon atom by the neighboring carbon atom to give the $\eta^{2}$-ketone species $K$. Dissociation of the ketone gives the product $L$. An alternative path to the production of the product from intermediate $I$ is by olefin-acyl insertion to 
give M. Reductive elimination by deuterium-carbon coupling in $\mathbf{M}$ gives the product $\mathbf{L}$. If $\beta$-hydride elimination is fast relative to the process $\mathbf{M} \rightarrow \mathbf{L}$, then the olefin complexes $\mathbf{N}$ and $\mathbf{Q}$ can form and olefin-deuterium insertion can give $\mathbf{O}$ and $\mathbf{R}$ which, in turn, can give the products $\mathbf{P}$ and $\mathbf{S}$, respectively. Provided the olefins of $\mathbf{N}$ and $\mathbf{Q}$ do not dissociate, the deuterium in $\mathbf{P}$ and $\mathbf{S}$ will reside trans to the tert-butyl group, as shown in $\mathbf{P}$ and $\mathbf{S}$. Such deuterium migration was observed for intramolecular hydrosilation with these catalysts, and a silyl-olefin insertion mechanism was inferred. ${ }^{19}$ Thus, if the olefin-acyl path were to occur in the present system, we would expect to find deuterium in the positions illustrated in $\mathbf{P}$ and $\mathbf{S}$.

When substrate 6 was catalyzed by the binap catalyst, the only product observed was $\mathbf{L}$, that is, deuterium was found only at the carbon bearing the tert-butyl group. This result implies that the equilibration of the type $B \rightleftarrows \mathbf{C}$ shown in Scheme 2 does not occur with substrate 6, perhaps because of steric hinderance that the tert-butyl group provides in destabilizing the intermediate $\mathbf{C}$. Further, the result suggests, but does not prove, that the olefinacyl insertion mechanism does not operate. If this is so, then the choice is between paths $\mathbf{J} \rightarrow \mathbf{K} \rightarrow \mathbf{L}$ or $\mathbf{J} \rightarrow \mathbf{L}$. Of these we prefer the former, in which the carbon atom bound to rhodium attacks the acyl group in the manner depicted in the sequence $\mathbf{7} \rightarrow \mathbf{1 0}$.

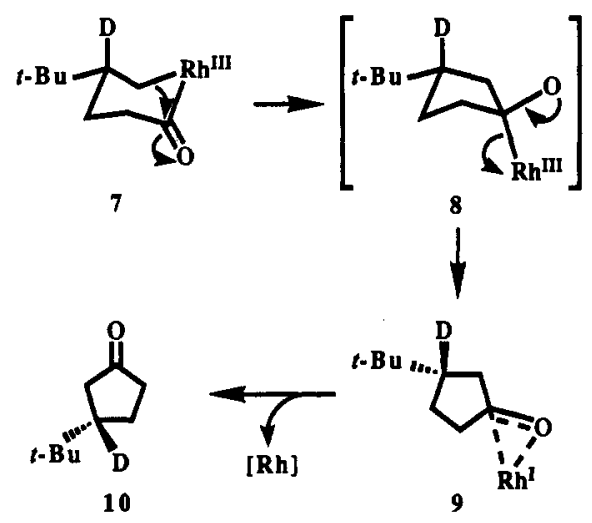

The reasons for this preference are based on a number of observations. It is known that acyl-alkyl reductive elimination is generally much faster than alkyl-alkyl elimination. ${ }^{20}$ This suggests that the former elimination may have access to a new mechanism for elimination. Thus it is attractive to view 7 as consisting of an acyl compound with a leaving group, the rhodium(III), and a cis-disposed alkylating agent, the rhodium-alkyl bond. The process $7 \rightarrow 9$ can then be viewed as the reaction of, for example, an ester with an organometallic reagent rather than as a $\sigma$-bond- $\sigma$-bond carbon-carbon coupling. The work of Suggs ${ }^{21}$ suggests that acyl-alkyl reductive elimination via the path depicted in the sequence $\mathbf{7 \rightarrow 1 0}$ is probable. It is possible, therefore, that the high turnover frequency observed for intramolecular hydroacylation is partly connected with the facile nature of acylalkyl reductive elimination.

4. Enantioselection. Inspection of the results listed in Tables 1,2 , and 3 elicit four interrelated questions. First, why is the binap catalyst so much more effective in the enantioselection of the substrates in Tables 2 and 3 than is the chiraphos analogue? Second, why do tertiary substituents at the 4-pentenal positions give almost complete enantioselectivity with the binap catalyst (Table 2)? Third, why do analogously positioned acyl substituents lead to high ees (Table 3)? Fourth, why do the $(S, S)$-chiraphos

(19) Bergens, S. H.; Noheda, P.; Whelan, J.; Bosnich, B. J. Am. Chem. Soc. 1992, 114, 2128.

(20) Brown, M. P.; Puddephatt, R. P.; Upton, C. E. E.; Lavington, S. W J. Chem. Soc, Dalton Trans. 1974, 1613 . Saunders, D. R.; Mawby, R. J. J. Chem. Soc., Dalton Trans. 1984, 2133. Evitt, E. R.; Bergman, R. G. J. Am. Chem. Soc. 1980, 102, 7003 . Ruddick, J. D.; Shaw, B. L. J. Chem. Soc. A 1969, 2969.

(21) Suggs, J. W.; Wovkulich, M. J. Organometallics 1985, 4, 1101. and $(S)$-binap catalysts give opposite prevailing chiralities of the products for the substrates listed in Tables 2 and 3 ? In an attempt to address these questions, we have made assumptions about the structure and reactivity of the monohydride intermediate (I, Scheme 3). We assume that the hydride will prefer to be cis rather than trans to the two phosphine ligands, that the coordinated carbon-carbon double bond axis will need to lie approximately (cis) coparallel to the $\mathrm{Rh}-\mathrm{H}$ axis for hydride-olefin insertion to occur, and that the major diastereomer will give the prevailing enantiomer of the product. Given these constraints, the key intermediate has the approximate square-pyramidal structure 11.

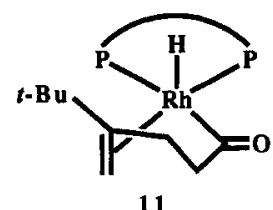

The major steric interaction between the chiral diphosphine ligands and the bound substrate is expected to be associated with the phenyl groups on the phosphorus and the substrate. ${ }^{12}$ The chiral diphosphine phenyl groups are fixed in a chiral array and are positioned axially (a) and equatorially (e) with respect to the mean molecular plane. ${ }^{12}$ Molecular models indicate, and crystal structures confirm, that these phenyl groups are more twisted in binap $^{13}$ than in chiraphos complexes. ${ }^{22}$ Further, the axially disposed phenyl groups of binap complexes are held closer to the chelate backbone, away from the bound substrate, than in chiraphos. The result is that the axial phenyl groups of binap are expected to interact less with the substrate than the axial phenyl groups in chiraphos catalysts. These differences are illustrated for $(S)$-binap (12) and for $(S, S)$-chiraphos (13) complexes. We suggest that these conformational differences are responsible for the different ees observed for the two catalysts.

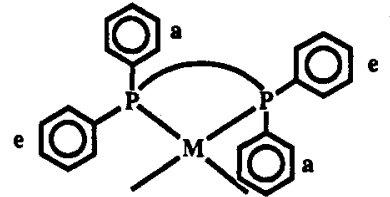

12

S.binap

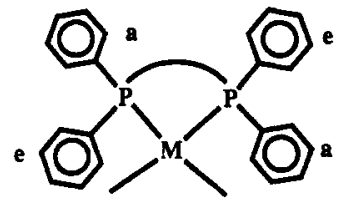

13

Assuming the structure 11, with its greater reactivity, and knowing that the prevailing product is $S$, we conclude that the preferred binding of the olefin group in the hydride intermediate 11 for $(S)$-binap is 14 and the less stable diastereomer is $\mathbf{1 5}$.

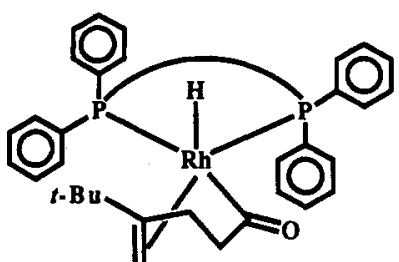

14

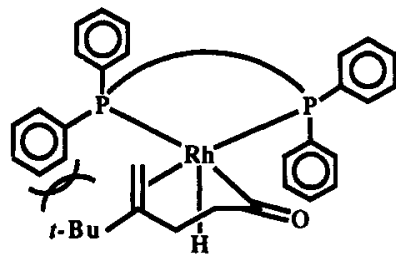

15

Molecular models suggest that the tert-butyl group or other tertiary substituents suffer strong steric interaction with the equatorial phenyl group of 15 , as shown, and thus destabilize 15 more than the same interactions destabilize 14. Because of the lesser twist of the chiraphos system, the differentiation between the two corresponding diastereomeric intermediates is less than in binap catalysts. The 4-acyl substituents, which are less bulky, may engage in secondary binding to the metal and thereby cause

(22) Ball, R. G.; Payne, N. C. Inorg. Chem. 1977, 16, 1187. 
substantial diastereomeric differentiation by restricting conformational adjustment of the interacting groups.

It will be noted that the twist sense of the phenyl groups in the $(S)$-binap (12) and $(S, S)$-chiraphos (13) catalysts is the same, and on this basis it might be expected that the two catalysts would give the same prevailing chirality of the products for the substrates listed in Tables 2 and 3. Opposite prevailing enantiomers are produced. This difference indicates that for the $(S, S)$ chiraphos catalyst the diastereomer which was more stable for the $(S)$-binap catalyst $(14)$ has become the less stable diastereomer, presumably because the axial phenyl group in $(S, S)$ chiraphos causes greater steric interaction with substrate. The greater axial phenyl group interaction probably arises because this phenyl group is less perpendicular to the mean molecular plane and lies closer to the substrate in the $(S, S)$-chiraphos catalyst than in the $(S)$-binap catalyst.

Since the detailed structures of the key intermediates are not known, it is not profitable to speculate further on the details of the different diastereomeric interactions which emanate from the two catalysts. It is important to note, however, that subtle conformational differences can have a significant effect on the practical outcome of these enantioselective reactions. Whatever the precise origins of the enantioselection with the binap catalyst, the present results indicate that high ees are likely to be observed with 4-substituted 4-pentenals when either a tertiary substituent is present or an $\alpha$-carbonyl group is incorporated.

\section{Experimental Section}

Reagents and solvents were purified by standard methods where necessary. For small-scale catalytic reactions, freshly opened ampules of acetone- $d_{6}$ and dichloromethane- $d_{2}$ were used as supplied by Aldrich Chemical Co., Inc. For large-scale catalytic reactions, acetone (3- $\AA$ molecular sieves) and dichloromethane $\left(\mathrm{CaH}_{2}\right)$ were distilled from the drying agents and deoxygenated by having argon bubbled through them. Hydrogen gas was purified by being passed through an Oxiclear oxygen and water scrubber. (S)-(-)-1-Amino-2-(methoxymethyl)pyrrolidine was used as obtained from Aldrich.

The following compounds were prepared according to literature methods: $\left[\mathrm{Rh}((S)\right.$-binap)(NBD) $] \mathrm{ClO}_{4},{ }^{13}[\mathrm{Rh}((S, S) \text {-chiraphos })]_{2}\left(\mathrm{ClO}_{4}\right)_{2},{ }^{7}$ ethylidenecyclohexylamine, ${ }^{23}$ 2-(1,1-dimethylethyl)-2-propen-1-ol, ${ }^{24}$ 2-methoxyphenylmagnesium bromide, ${ }^{25}$ 4-methoxyphenylmagnesium bromide, ${ }^{26} 1$-methylethyl chloroacetate, ${ }^{27} 1$-methylethyl diethoxyphosphinylacetate, ${ }^{28}$ 4-bromo-4-pentenal, ${ }^{15}$ ethyl $\alpha$-hydroxymethylacrylate, ${ }^{29}$ and dichloro-(1,3-bis(diphenylphosphino)propane)nickel ( $\mathrm{NiCl}_{2}(\mathrm{dppp})$ ). ${ }^{30}$

Aldehyde Substrates. The 4-pentenal substrates were prepared by four general methods as shown in Scheme 1. The first method was the $\mathrm{Hg}^{2+}$-catalyzed vinylation of 2-substituted allyl alcohols followed by a Claissen rearrangement. ${ }^{14}$ The second method was the two-carbon homologation of 2-substituted allyl iodides by 2-lithioethylidenecyclohexylamine followed by acid hydrolysis. ${ }^{15}$ The third method was the nickel(II)-catalyzed cross-coupling ${ }^{16}$ between 4-bromo-4-pentenal dimethyl acetal and Grignard reagents followed by acid hydrolysis. The fourth method was reaction between 4-lithio-4-pentenal dimethyl acetal and electrophiles ${ }^{17}$ followed by acid hydrolysis. The acid hydrolyses of the dimethyl acetals to the aldehyde substrates were quite sensitive to the reaction conditions. The following methods were used: (method $A$ ) the acetal $(28.3 \mathrm{mmol})$, THF $(125 \mathrm{~mL})$, and $15 \%$ aqueous tartaric acid $(250$ $\mathrm{mL}, 250 \mathrm{mmol})$ were stirred at $25^{\circ} \mathrm{C}$; (method B) the acetal $(29.3 \mathrm{mmol})$, THF $(165 \mathrm{~mL})$, and $10 \%$ aqueous tartaric acid $(120 \mathrm{~mL}, 80 \mathrm{mmol})$ were stirred at $25^{\circ} \mathrm{C}$; (method C) the acetal $(24.0 \mathrm{mmol})$, THF $(220 \mathrm{~mL})$, and $1 \mathrm{~N} \mathrm{HCl}(22 \mathrm{~mL}, 22 \mathrm{mmol})$ were stirred at $25^{\circ} \mathrm{C}$; (method D) the acetal $(38.3 \mathrm{mmol})$, THF $(180 \mathrm{~mL})$, and $1 \mathrm{~N} \mathrm{HCl}(60 \mathrm{~mL}, 60 \mathrm{mmol})$

(23) Wittig, G.; Hesse, A. Org. Synth. 1970, 50, 66.

(24) Barleunga, J.; Fernández-Simón, J. L.; Concellón, J. M.; Yus, M. J. Chem. Soc., Perkin Trans. 1 1989, 77.

(25) Sisti, A. J. Organic Syntheses; Wiley: New York, 1973; Collect. Vol. $\mathrm{V}, \mathrm{p} 46$.

(26) Manya, P.; Sekera, A.; Rumpf, P. Tetrahedron 1970, 26, 467.

(27) Prato, M.; Quintily, U.; Scorrano, G. J. Chem. Soc., Perkin Trans. $21986,1419$.

(28) Ye, W.; Liao, X. Synthesis 1985, 986.

(29) Villieras, J.; Rambaud, M. Synthesis 1982, 924

(30) Van Hecke, G. R.; Horrocks, W. De W., Jr. Inorg. Chem. 1966, 5 , 1968. were stirred at $25^{\circ} \mathrm{C}$; (method E) $)^{31}$ the acetal $(8.3 \mathrm{mmol}), \mathrm{THF}(34 \mathrm{~mL})$, $37 \%$ aqueous formaldehyde $(17 \mathrm{~mL}, 230 \mathrm{mmol})$, and pyridino-ptoluenesulfonate $(2.1 \mathrm{~g}, 8.3 \mathrm{mmol})$ were stirred at $25^{\circ} \mathrm{C}$; and (method F) ${ }^{32}$ the acetal $(17.7 \mathrm{mmol})$, distilled dimethyl sulfoxide $(2.5 \mathrm{~mL}, 35$ $\mathrm{mmol}), \mathrm{H}_{2} \mathrm{O}(8.9 \mathrm{~mL}, 490 \mathrm{mmol})$, and distilled $p$-dioxane $(35 \mathrm{~mL})$ were refluxed under nitrogen.

Method 1. 2-(Ethoxycarbonyl)-4-pentenal. A mixture of ethyl $\alpha$-hydroxymethacrylate ${ }^{29}(9.00 \mathrm{~g}, 69.2 \mathrm{mmol})$, butyl vinyl ether (160 $\mathrm{mL})$ and $\mathrm{Hg}(\mathrm{OAc})_{2}(4.00 \mathrm{~g}, 12.6 \mathrm{mmol})$ was refluxed under argon for $25 \mathrm{~h}$. The mixture was cooled to $0^{\circ} \mathrm{C}$, and $10 \%$ aqueous $\mathrm{Na}_{2} \mathrm{CO}_{3}(100$ $\mathrm{mL}$ ) was added over $15 \mathrm{~min}$. The mixture was stirred for $30 \mathrm{~min}$ while being allowed to warm to room temperature. The aqueous phase was extracted with $\mathrm{Et}_{2} \mathrm{O}(3 \times 150 \mathrm{~mL})$. The combined organic layers were washed with brine $(100 \mathrm{~mL})$ and dried $\left(\mathrm{MgSO}_{4}\right)$. After filtration through Celite, the solvents were removed under reduced pressure $(0.4 \mathrm{~mm}, 25$ ${ }^{\circ} \mathrm{C}$ ). The residue was purified by flash chromatography (silica gel, hexane then $\mathrm{CH}_{2} \mathrm{Cl}_{2}$ ) followed by distillation to give 2-(ethoxycarbonyl)-4pentenal as a colorless oil: $4.66 \mathrm{~g}, 43 \%$ yield; bp $52-55^{\circ} \mathrm{C}(0.4 \mathrm{mmHg})$; ${ }^{1} \mathrm{H}$ NMR $\left(400 \mathrm{MHz}, \mathrm{CDCl}_{3}\right) \delta 9.79(\mathrm{~s}, 1 \mathrm{H}), 6.21(\mathrm{~s}, 1 \mathrm{H}), 5.60(\mathrm{~s}, 1$ $\mathrm{H}), 4.22(\mathrm{q}, J=7.1 \mathrm{~Hz}, 2 \mathrm{H}), 2.66(\mathrm{~s}, 4 \mathrm{H}), 1.31(\mathrm{t}, J=7.1 \mathrm{~Hz}, 3 \mathrm{H})$. Cyclopentanone product: ${ }^{1} \mathrm{H}$ NMR $\left(500 \mathrm{MHz}, \mathrm{CDCl}_{3}\right) \delta 4.19(\mathrm{q}, J=$ $7.1 \mathrm{~Hz}, 2 \mathrm{H}), 3.19-3.07(\mathrm{~m}, 1 \mathrm{H}), 2.55-2.08(\mathrm{~m}, 7 \mathrm{H}), 1.26(\mathrm{t}, J=7.1$ $\mathrm{Hz}, 3 \mathrm{H})$.

4-(Methylethoxycarbonyl)-4-pentenal. This compound was similarly prepared from methylethyl $\alpha$-hydroxymethacrylate (prepared from 1-methylethyl diethoxyphosphinylacetate ${ }^{28}$ by a Wittig-Horner elimination $^{29}$ in a $65 \%$ yield). The produce was purified by flash chromatography (silica gel, $75 \% \mathrm{CH}_{2} \mathrm{Cl}_{2}$ /hexane) followed by distillation giving a colorless oil: $14 \%$ yield (based on methylethyl $\alpha$-hydroxymethacrylate); bp $52{ }^{\circ} \mathrm{C}(0.4 \mathrm{mmHg}) ;{ }^{1} \mathrm{H}$ NMR $\left(300 \mathrm{MHz}, \mathrm{CDCl}_{3}\right) \delta 9.79(\mathrm{~s}, 1 \mathrm{H})$, $6.19(\mathrm{~s}, 1 \mathrm{H}), 5.57(\mathrm{~s}, 1 \mathrm{H}), 5.08(\mathrm{~h}, J=6.3 \mathrm{~Hz}, 1 \mathrm{H}), 2.66(\mathrm{~s}, 4 \mathrm{H})$, $1.28(\mathrm{~d}, J=6.3 \mathrm{~Hz}, 6 \mathrm{H})$. Cyclopentanone product: ${ }^{1} \mathrm{H}$ NMR $(300$ $\left.\mathrm{MHz} \mathrm{CDCl}_{3}\right) \delta 4.99(\mathrm{~h}, J=6.3 \mathrm{~Hz}, 1 \mathrm{H}), 3.12-3.00(\mathrm{~m}, 1 \mathrm{H}), 2.55-2.04$ $(\mathrm{m}, 6 \mathrm{H}), 1.21(\mathrm{~d}, J=6.3 \mathrm{~Hz}, 6 \mathrm{H})$.

Method 2. 4-Methyl-4-pentenal. 2-Methyl-2-propen-1-ol was converted to the mesylate in almost quantitative yield by the method of Servis. ${ }^{33}$ This was transformed in situ to the iodide (NaI in THF) and reacted with 2-lithioethylidenecyclohexylamine followed by acid hydrolysis by the method of Le Borgne. ${ }^{15}$ The product was purified by distillation, giving a pale yellow oil: $40 \%$ yield (based on 2-methyl-2-propen-1-ol); bp $43-46^{\circ} \mathrm{C}(40 \mathrm{mmHg}) ;{ }^{1} \mathrm{H}$ NMR $\left(500 \mathrm{MHz}, \mathrm{CDCl}_{3}\right) \delta 9.72(\mathrm{t}, J=$ $1.6 \mathrm{~Hz}, 1 \mathrm{H}), 4.75(\mathrm{~s}, 1 \mathrm{H}), 4.66(\mathrm{~s}, 1 \mathrm{H}), 2.58-2.55(\mathrm{~m}, 2 \mathrm{H}), 2.35-2.32$ $(\mathrm{m}, 2 \mathrm{H}), 1.74(\mathrm{~s}, 3 \mathrm{H})$. Cyclopentanone product: ' $\mathrm{H} \mathrm{NMR}(500 \mathrm{MHz}$, $\left.\mathrm{CDCl}_{3}\right) \delta 2.43-2.25(\mathrm{~m}, 3 \mathrm{H}), 2.25-2.14(\mathrm{~m}, 2 \mathrm{H}), 1.84-1.78(\mathrm{~m}, 1 \mathrm{H})$, $1.62-1.50(\mathrm{~m}, 1 \mathrm{H}), 1.16(\mathrm{~d}, J=6.4 \mathrm{~Hz}, 3 \mathrm{H})$.

4-(1,1-Dimethylethyl)-4-pentenal. This compound was prepared by the same method from 2-(1,1-dimethylethyl)-2-propen-1-ol ${ }^{24}$ and purified by distillation followed by flash chromatography (silica gel, $8 \%$ ethyl acetate/hexane), giving a colorless oil: $52 \%$ yield (based on 2-(1,1dimethylethyl)-2-propen-1-ol); bp 90-95 ${ }^{\circ} \mathrm{C}(40 \mathrm{mmHg}) ;{ }^{1} \mathrm{H} \mathrm{NMR}(300$ $\left.\mathrm{MHz}, \mathrm{CDCl}_{3}\right) \delta 9.79(\mathrm{t}, J=1.6 \mathrm{~Hz}, 1 \mathrm{H}), 4.92(\mathrm{~s}, 1 \mathrm{H}), 4.62(\mathrm{~m}, 1 \mathrm{H})$, 2.65-2.59 (m, $2 \mathrm{H}), 2.43-2.38(\mathrm{~m}, 2 \mathrm{H}), 1.08(\mathrm{~s}, 9 \mathrm{H})$. Cyclopentanone product: ${ }^{1} \mathrm{H}$ NMR (400 MHz, $\left.\mathrm{CDCl}_{3}\right) \delta 2.38-2.30(\mathrm{~m}, 1 \mathrm{H}), 2.27-2.11$ (m, $2 \mathrm{H}), 2.06-1.88(\mathrm{~m}, 3 \mathrm{H}) ; 1.65-1.52(\mathrm{~m}, 1 \mathrm{H}), 0.92(\mathrm{~s}, 9 \mathrm{H}) ;{ }^{1} \mathrm{H}$ NMR (400 MHz, $\left.\mathrm{C}_{6} \mathrm{D}_{6}\right) \delta 2.01-1.92(\mathrm{~m}, 1 \mathrm{H}), 1.92-1.84(\mathrm{~m}, 1 \mathrm{H})$, $1.78-1.65(\mathrm{~m}, 1 \mathrm{H}), 1.58-1.48(\mathrm{~m}, 1 \mathrm{H}), 1.43-1.30(\mathrm{~m}, 2 \mathrm{H}), 1.05-0.91$ $(\mathrm{m}, 1 \mathrm{H}), 0.61(\mathrm{~s}, 9 \mathrm{H})$

Method 3. 4-Bromo-4-pentenal Dimethyl Acetal. 4-Bromo-4-pentenal (40.09 $\mathrm{g}$, crude as obtained from 2,3-dibromopropene using the method of Le Borgne, ${ }^{15} \mathrm{ca} .0 .17 \mathrm{~mol}$ of pentenal), $\mathrm{MeOH}(450 \mathrm{~mL})$, trimethyl orthoformate ( $95 \mathrm{~mL}, 868 \mathrm{mmol}$ ), and $p$-toluenesulfonic acid monohydrate $(0.64 \mathrm{~g}, 3.4 \mathrm{mmol})$ were stirred under argon overnight and then poured into dilute aqueous $\mathrm{NaHCO}_{3}\left(12 \mathrm{~g}\right.$ in $\left.2.2 \mathrm{~L} \mathrm{H}_{2} \mathrm{O}\right)$, and the mixture was extracted with $\mathrm{Et}_{2} \mathrm{O}(4 \times 200 \mathrm{~mL})$. The combined organic layers were washed with $\mathrm{H}_{2} \mathrm{O}(2 \times 200 \mathrm{~mL})$ and brine $(1 \times 200 \mathrm{~mL})$ and dried $\left(\mathrm{Na}_{2} \mathrm{SO}_{4}\right)$. Filtration, removal of solvents under reduced pressure, and distillation through a vigreaux column gave a colorless oil: $35.07 \mathrm{~g}, 62 \%$ yield (based on 2,3-dibromopropene); bp $58{ }^{\circ} \mathrm{C}(4 \mathrm{mmHg}) ;{ }^{1} \mathrm{H}$ NMR $\left(300 \mathrm{MHz}, \mathrm{CDCl}_{3}\right) \delta 5.61(\mathrm{~m}, 1 \mathrm{H}), 5.41(\mathrm{~m}, 1 \mathrm{H}), 4.39(\mathrm{t}, J=5.7 \mathrm{~Hz}$, $1 \mathrm{H}), 3.34$ (s, $6 \mathrm{H}), 2.52-2.47$ (m, $2 \mathrm{H}), 1.91-1.84(\mathrm{~m}, 2 \mathrm{H})$. 3772 .

(31) Miyashita, M.; Yoshikoshi, A.; Grieco, P. J. Org. Chem. 1977, 42,

(32) Kametani, T.; Kondoh, H.; Honda, T.; Ishizone, H.; Suzuki, Y.; Mori, W. Chem. Lett. 1989, 901 .

(33) Crossland, R. K.; Servis, K. L. J. Org. Chem. 1970, 35, 3195. 
4-p-Tolyl-4pentenal. p-Tolymagnesium bromide in $\mathrm{Et}_{2} \mathrm{O}$ (1.0 M, 25.0 $\mathrm{mL}, 25.0 \mathrm{mmol}$ ) was added dropwise at $0^{\circ} \mathrm{C}$ over $15 \mathrm{~min}$ to a stirred mixture of 4-bromo-4-pentenal dimethyl acetal $(5.44 \mathrm{~g}, 24.4 \mathrm{mmol})$ and $\left[\mathrm{NiCl}_{2}(\mathrm{dppp})\right]^{30}(0.13 \mathrm{~g}, 0.24 \mathrm{mmol})$ in dry $\mathrm{Et}_{2} \mathrm{O}(25 \mathrm{~mL})$ under nitrogen. The reaction mixture was refluxed for $17 \mathrm{~h}$ and then was cooled to room temperature and quenched by the dropwise addition of $5 \%$ aqueous $\mathrm{NH}_{4}$ $\mathrm{OAc}(50 \mathrm{~mL})$. The aqueous layer was extracted with $\mathrm{Et}_{2} \mathrm{O}(2 \times 50 \mathrm{~mL})$. The combined organic layers were filtered through paper and then washed with $\mathrm{H}_{2} \mathrm{O}(3 \times 75 \mathrm{~mL})$. The solvents were removed under reduced pressure, and to the residue was added THF $(110 \mathrm{~mL})$ and $15 \%$ aqueous tartaric acid $(220 \mathrm{~mL})$ (hydrolysis method A). After being stirred at room temperature for $75 \mathrm{~h}$, the reaction mixture was extracted with $\mathrm{Et}_{2} \mathrm{O}$ $(3 \times 150 \mathrm{~mL})$. The combined extracts were washed with $\mathrm{H}_{2} \mathrm{O}(2 \times 150$ $\mathrm{mL})$, saturated aqueous $\mathrm{NaHCO}_{3}(1 \times 150 \mathrm{~mL}), \mathrm{H}_{2} \mathrm{O}(1 \times 150 \mathrm{~mL})$, and brine $(1 \times 150 \mathrm{~mL})$ and dried $\left(\mathrm{Na}_{2} \mathrm{SO}_{4}\right)$. The solvents were removed under reduced pressure, and the residue was purified by flash chromatography (silica gel, $10 \%$ ethyl acetate/hexane), giving a light yellow oil: $3.57 \mathrm{~g}, 84 \%$ yield; ${ }^{1} \mathrm{H}$ NMR $\left(300 \mathrm{MHz}, \mathrm{CDCl}_{3}\right) \delta 9.78(\mathrm{t}, J=1.5 \mathrm{~Hz}$, $1 \mathrm{H})$, 7.4-7.1 (m, $4 \mathrm{H}), 5.30(\mathrm{~s}, 1 \mathrm{H}), 5.05(\mathrm{~m}, 1 \mathrm{H}), 2.86-2.81(\mathrm{~m}, 2$ $\mathrm{H}), 2.63-2.57(\mathrm{~m}, 2 \mathrm{H}), 2.35(\mathrm{~s}, 3 \mathrm{H})$. Cyclopentanone product: ${ }^{1} \mathrm{H}$ $\operatorname{NMR}\left(500 \mathrm{MHz}, \mathrm{CDCl}_{3}\right) \delta 7.21(\mathrm{~s}, 4 \mathrm{H}), 3.40-3.33(\mathrm{~m}, 1 \mathrm{H}), 2.66-2.60$ (m, $1 \mathrm{H}), 2.47-2.38(\mathrm{~m}, 2 \mathrm{H}), 2.36-2.20(\mathrm{~m}, 2 \mathrm{H}), 2.33(\mathrm{~s}, 3 \mathrm{H}), 2.00$ $1.91(\mathrm{~m}, 1 \mathrm{H})$.

4-(Methylethyl)-4-pentenal. This compound was prepared by the same nickel coupling method described above and hydrolysis method $\mathrm{A}$ (110 h). It was purified by flash chromatography (silica gel, $50 \% \mathrm{CH}_{2} \mathrm{Cl}_{2}$ / pentane), giving a pale yellow oil: $59 \%$ yield; ${ }^{1} \mathrm{H}$ NMR $(300 \mathrm{MHz}$, $\left.\mathrm{CDCl}_{3}\right) \delta 9.79(\mathrm{t}, J=1.7 \mathrm{~Hz}, 1 \mathrm{H}), 4.82(\mathrm{~m}, 1 \mathrm{H}), 4.65(\mathrm{~m}, 1 \mathrm{H})$ 2.63-2.57 (m, $2 \mathrm{H}), 2.40-2.35(\mathrm{~m}, 2 \mathrm{H}), 2.26(\mathrm{~h}, J=6.8 \mathrm{~Hz}, 1 \mathrm{H}), 1.01$ $(\mathrm{d}, J=6.8 \mathrm{~Hz}, 6 \mathrm{H})$. Cyclopentanone product: ${ }^{1} \mathrm{H} \mathrm{NMR}(500 \mathrm{MHz}$, $\left.\mathrm{CDCl}_{3}\right) \delta 2.40-2.28(\mathrm{~m}, 2 \mathrm{H}), 2.18-2.10(\mathrm{~m}, 2 \mathrm{H}), 1.85-1.78(\mathrm{~m}, 2 \mathrm{H})$, $1.55-1.45(\mathrm{~m}, 2 \mathrm{H}), 0.96(\mathrm{~d}, J=6.7 \mathrm{~Hz}, 3 \mathrm{H}), 0.93(\mathrm{~d}, J=6.7 \mathrm{~Hz}, 3$ H).

4-Cyclopentyl-4-pentenal. This compound was prepared by the same method as above and hydrolysis method $A(80 \mathrm{~h})$. It was purified by flash chromatography (silica gel, $8 \%$ ethyl acetate/hexane), giving a colorless oil: $59 \%$ yield; ${ }^{1} \mathrm{H}$ NMR $\left(300 \mathrm{MHz}, \mathrm{CDCl}_{3}\right) \delta 9.79(\mathrm{t}, J=1.7$ $\mathrm{Hz}, 1 \mathrm{H}), 4.83(\mathrm{~s}, 1 \mathrm{H}), 4.66(\mathrm{~s}, 1 \mathrm{H}), 2.63-2.58(\mathrm{~m}, 2 \mathrm{H}), 2.41-2.36$ $(\mathrm{m}, 2 \mathrm{H}), 1.9-1.3(\mathrm{~m}, 9 \mathrm{H})$. Cyclopentanone product: ${ }^{1} \mathrm{H}$ NMR (500 $\left.\mathrm{MHz}, \mathrm{CDCl}_{3}\right) \delta 2.40-2.22(\mathrm{~m}, 2 \mathrm{H}), 2.22-2.02(\mathrm{~m}, 2 \mathrm{H}), 2.02-1.45(\mathrm{~m}$, $10 \mathrm{H}), 1.33-1.08(\mathrm{~m}, 2 \mathrm{H})$.

4-Cyclobexyl-4-pentenal. This compound was prepared by the same method as above and hydrolysis method $(75 \mathrm{~h})$. It was purified by flash chromatography (silica gel, $50 \% \mathrm{CH}_{2} \mathrm{Cl}_{2}$ /hexane), giving a colorless oil: $62 \%$ yield; ${ }^{1} \mathrm{H}$ NMR $\left(300 \mathrm{MHz}, \mathrm{CDCl}_{3}\right) \delta 9.78(\mathrm{t}, J=1.7 \mathrm{~Hz}, 1 \mathrm{H})$, $4.79(\mathrm{~m}, 1 \mathrm{H}), 4.66(\mathrm{~m}, 1 \mathrm{H}), 2.6-2.5(\mathrm{~m}, 2 \mathrm{H}), 2.4-2.3(\mathrm{~m}, 2 \mathrm{H}), 1.9-1.1$ $(\mathrm{m}, 11 \mathrm{H})$. Cyclopentanone product: 'H NMR $\left(500 \mathrm{MHz}, \mathrm{CDCl}_{3}\right) \delta$ 2.40-2.25 (m, $2 \mathrm{H}), 2.25-2.05(\mathrm{~m}, 2 \mathrm{H}), 1.95-1.60(\mathrm{~m}, 7 \mathrm{H}), 1.54-1.42$ (m, $1 \mathrm{H}), 1.30-1.10(\mathrm{~m}, 4 \mathrm{H}), 1.13-0.90(\mathrm{~m}, 2 \mathrm{H})$.

4-Phenyl-4-pentenal. This compound was prepared by the above method and hydrolysis method $A(60 \mathrm{~h})$. It was purified by flash chromatography (silica gel, $10 \%$ ethyl acetate/hexane), giving a colorless oil: $75 \%$ yield; bp $71-76^{\circ} \mathrm{C}(0.4 \mathrm{mmHg}){ }^{1} \mathrm{H}$ NMR $\left(500 \mathrm{MHz}, \mathrm{CDCl}_{3}\right)$ $\delta 9.72(\mathrm{~s}, 1 \mathrm{H}), 7.4-7.2(\mathrm{~m}, 5 \mathrm{H}), 5.29$ (br s, $1 \mathrm{H}), 5.06$ (br s, $1 \mathrm{H}), 2.83$ $(\mathrm{t}, J=7.3 \mathrm{~Hz}, 2 \mathrm{H}), 2.59(\mathrm{t}, J=7.3 \mathrm{~Hz}, 2 \mathrm{H})$. Cyclopentanone product: ${ }^{1} \mathrm{H}$ NMR ( $\left.500 \mathrm{MHz}, \mathrm{CDCl}_{3}\right) \delta$ 7.38-7.22 (m, $\left.5 \mathrm{H}\right), 3.46-3.38(\mathrm{~m}, 1 \mathrm{H})$, 2.69- $2.64(\mathrm{~m}, 1 \mathrm{H}), 2.50-2.41(\mathrm{~m}, 2 \mathrm{H}), 2.38-2.25(\mathrm{~m}, 2 \mathrm{H}), 2.04-1.93$ (m, $1 \mathrm{H})$.

4-(2-Methoxyphenyl)-4-pentenal. This compound was prepared from 2-methoxyphenylmagnesium bromide ${ }^{25}$ by the above nickel coupling method and hydrolysis method B $(70 \mathrm{~h})$. It was purified by flash chromatography (silica gel, $67 \% \mathrm{CH}_{2} \mathrm{Cl}_{2}$ /hexane), giving a colorless oil: $61 \%$ yield; ' $\mathrm{H}$ NMR ( $\left.300 \mathrm{MHz}, \mathrm{CDCl}_{3}\right) \delta 9.73(\mathrm{t}, J=1.7 \mathrm{~Hz}, 1 \mathrm{H})$, 7.3-6.8 (m, $4 \mathrm{H}), 5.17(\mathrm{~m}, 1 \mathrm{H}), 5.06(\mathrm{~m}, 1 \mathrm{H}), 3.82(\mathrm{~s}, 3 \mathrm{H}), 2.86-2.81$ (m, $2 \mathrm{H}), 2.51-2.46(\mathrm{~m}, 2 \mathrm{H})$. Cyclopentanone product: 'H NMR (400 $\left.\mathrm{MHz}_{2} \mathrm{CDCl}_{3}\right) 87.26-7.16(\mathrm{~m}, 2 \mathrm{H}), 6.98-6.87(\mathrm{~m}, 2 \mathrm{H}), 3.77(\mathrm{~s}, 3 \mathrm{H})$, $3.74-3.64(\mathrm{~m}, 1 \mathrm{H}), 2.68-2.60(\mathrm{~m}, 1 \mathrm{H}), 2.47-2.25(\mathrm{~m}, 4 \mathrm{H}), 2.10-1.99$ $(\mathrm{m}, 1 \mathrm{H})$.

4-(4-Methoxyphenyl)-4-pentenal. This compound was prepared from 4-methoxyphenylmagnesium bromide ${ }^{26}$ by the above nickel coupling method and hydrolysis method $\mathrm{A}(70 \mathrm{~h})$. It was purified by flash chromatography (silica gel, $75 \% \mathrm{CH}_{2} \mathrm{Cl}_{2}$ /hexane), giving a white crystalline low-melting solid: $55 \%$ yield; ${ }^{1} \mathrm{H}$ NMR $\left(500 \mathrm{MHz}, \mathrm{CDCl}_{3}\right)$ $\delta 9.72(\mathrm{~s}, 1 \mathrm{H}), 7.28(\mathrm{~d}, J=8.6 \mathrm{~Hz}, 2 \mathrm{H}), 6.83(\mathrm{~d}, J=8.6 \mathrm{~Hz}, 2 \mathrm{H})$ $5.22(\mathrm{~s}, 1 \mathrm{H}), 4.98(\mathrm{~s}, 1 \mathrm{H}), 3.79(\mathrm{~s}, 3 \mathrm{H}), 2.82-2.79(\mathrm{~m}, 2 \mathrm{H}), 2.60-2.57$ (m, $2 \mathrm{H})$. Cyclopentanone product: ' $\mathrm{H}$ NMR $\left(300 \mathrm{MHz}, \mathrm{CDCl}_{3}\right) \delta$
7.20-7.16 (m, $2 \mathrm{H}), 6.91-6.87(\mathrm{~m}, 2 \mathrm{H}), 3.81(\mathrm{~s}, 3 \mathrm{H}), 3.44-3.31(\mathrm{~m}$, $1 \mathrm{H}), 2.70-2.60(\mathrm{~m}, 1 \mathrm{H}), 2.55-2.20(\mathrm{~m}, 4 \mathrm{H}), 2.02-1.88(\mathrm{~m}, 1 \mathrm{H})$.

Method 4a. 4(Methyldiphenylsilyl)-4-pentenal. tert-Butyllithium in pentane $(1.7 \mathrm{M}, 56 \mathrm{~mL}, 95.1 \mathrm{mmol})$ was added dropwise over $15 \mathrm{~min}$ to a stirring solution of 4-bromo-4-pentenal dimethyl acetal $(9.47 \mathrm{~g}, 45.3$ $\mathrm{mmol})$ in dry $\mathrm{Et}_{2} \mathrm{O}(250 \mathrm{~mL})$ at $-78^{\circ} \mathrm{C}$ under nitrogen. After the solution was stirred for $2 \mathrm{~h}$ at $-78^{\circ} \mathrm{C}$, chloromethyldiphenylsilane $(9.5 \mathrm{~mL}, 45.2$ $\mathrm{mmol}$ ) was added dropwise over $10 \mathrm{~min}$, and the solution was allowed to warm to room temperature over $1 \mathrm{~h}$. The solution was stirred for 25 $\mathrm{h}$ at $25^{\circ} \mathrm{C}$, and then it was poured into $5 \%$ aqueous $\mathrm{NH}_{4} \mathrm{OAc}(1000 \mathrm{~mL})$ at $0^{\circ} \mathrm{C}$. The aqueous layer was extracted with $\mathrm{Et}_{2} \mathrm{O}(3 \times 200 \mathrm{~mL})$. The combined organic layers were washed with $\mathrm{H}_{2} \mathrm{O}(2 \times 200 \mathrm{~mL})$ and brine $(1 \times 200 \mathrm{~mL})$ and dried $\left(\mathrm{Na}_{2} \mathrm{SO}_{4}\right)$. After filtration, the solvents were removed under reduced pressure, and to the residue were added THF $(410 \mathrm{~mL})$ and $1 \mathrm{M} \mathrm{HCl}(41 \mathrm{~mL})$ (hydrolysis method C). After the mixture was stirred at room temperature for $35 \mathrm{~h}, \mathrm{H}_{2} \mathrm{O}(1000 \mathrm{~mL})$ was added, and the mixture was extracted with $\mathrm{Et}_{2} \mathrm{O}(3 \times 200 \mathrm{~mL})$. The combined organic extracts were washed with $\mathrm{H}_{2} \mathrm{O}(1 \times 200 \mathrm{~mL}), 5 \%$ aqueous $\mathrm{NaHCO}_{3}(1 \times 200 \mathrm{~mL}), \mathrm{H}_{2} \mathrm{O}(3 \times 200 \mathrm{~mL})$, and brine $(1 \times$ $200 \mathrm{~mL}$ ) and dried $\left(\mathrm{Na}_{2} \mathrm{SO}_{4}\right)$. After filtration, the solvents were removed under reduced pressure and the residue was purified by flash chromatography (silica gel, $10 \%$ ethyl acetate/hexane), giving a yellow oil: 8.05 g, $47 \%$ yield; bp $121-122^{\circ} \mathrm{C}(0.4 \mathrm{mmHg}) ;{ }^{1} \mathrm{H}$ NMR ( $\left.300 \mathrm{MHz}, \mathrm{CDCl}_{3}\right)$ $\delta 9.65(\mathrm{~s}, 1 \mathrm{H}), 7.6-7.3(\mathrm{~m}, 10 \mathrm{H}), 5.82(\mathrm{br} \mathrm{s}, 1 \mathrm{H}), 5.47$ (br s, $1 \mathrm{H})$, 2.55-2.45 (m, $4 \mathrm{H}), 0.67(\mathrm{~s}, 3 \mathrm{H})$. Cyclopentanone product: ' ${ }^{1} \mathrm{H}$ NMR $\left(300 \mathrm{MHz} \mathrm{CDCl}_{3}\right) \delta$ 7.58-7.47 (m, $\left.4 \mathrm{H}\right), 7.47-7.33(\mathrm{~m}, 6 \mathrm{H}), 2.46-2.29$ (m, $1 \mathrm{H}), 2.29-2.08(\mathrm{~m}, 3 \mathrm{H}), 2.08-1.88(\mathrm{~m}, 2 \mathrm{H}), 1.83-1.69(\mathrm{~m}, 1 \mathrm{H})$, $0.60(\mathrm{~s}, 3 \mathrm{H})$

4-(Trimethylsilyl)-4-pentenal. This compound was similarly prepared from chlorotrimethylsilane and 4-lithio-4-pentenal dimethyl acetal using hydrolysis method $\mathrm{C}(25 \mathrm{~h})$. The product was purified by distillation, giving a pale yellow oil: $53 \%$ yield; bp $94-99^{\circ} \mathrm{C}(40 \mathrm{mmHz}){ }^{1} \mathrm{H}$ NMR $\left(300 \mathrm{MHz}, \mathrm{CDCl}_{3}\right) \delta 9.78(\mathrm{t}, J=1.7 \mathrm{~Hz}, 1 \mathrm{H}), 5.54(\mathrm{~m}, 1 \mathrm{H}), 5.37(\mathrm{~m}$, $1 \mathrm{H}), 2.65-2.53(\mathrm{~m}, 2 \mathrm{H}), 2.53-2.40(\mathrm{~m}, 2 \mathrm{H}), 0.10(\mathrm{~s}, 9 \mathrm{H})$. Cyclopentanone product: 'H NMR (400 MHz, $\left.{ }^{2} \mathrm{CDCl}_{3}\right) \delta 2.32-2.22(\mathrm{~m}$, $2 \mathrm{H}), 2.20-2.04(\mathrm{~m}, 2 \mathrm{H}), 1.92-1.82(\mathrm{~m}, 1 \mathrm{H}), 1.72-1.59(\mathrm{~m}, 1 \mathrm{H})$, $1.38-1.24(\mathrm{~m}, 1 \mathrm{H}), 0.03(\mathrm{~s}, 9 \mathrm{H})$.

4-(Dimethylphenylsilyl)-4-pentenal. This compound was similarly prepared except the chlorodimethylphenylsilane and the 4-lithio-4pentenal dimethyl acetal were stirred for $6 \mathrm{~h}$ at room temperature. The acetal was hydrolyzed by method $\mathrm{C}(20 \mathrm{~h})$, and the product was purified by distillation ( $2 X)$, giving a colorless oil: $52 \%$ yield; bp $74-76^{\circ} \mathrm{C}(0.4$ mmHg); ${ }^{\mathrm{H}} \mathrm{NMR}\left(500 \mathrm{MHz}, \mathrm{CDCl}_{3}\right) \delta 9.61(\mathrm{~s}, 1 \mathrm{H}), 7.5-7.3(\mathrm{~m}, 5 \mathrm{H})$, $5.63(\mathrm{~s}, 1 \mathrm{H}), 5.44(\mathrm{~s}, 1 \mathrm{H}), 2.5-2.4(\mathrm{~m}, 4 \mathrm{H}), 0.39(\mathrm{~s}, 6 \mathrm{H})$. Cyclopentanone product: 'H NMR ( $\left.500 \mathrm{MHz}, \mathrm{CDCl}_{3}\right) \delta 7.48-7.30(\mathrm{~m}$, $5 \mathrm{H}), 2.28-2.17(\mathrm{~m}, 2 \mathrm{H}), 2.13-2.04(\mathrm{~m}, 2 \mathrm{H}), 1.91-1.84(\mathrm{~m}, 1 \mathrm{H})$, $1.69-1.62(\mathrm{~m}, 1 \mathrm{H}), 1.57-1.52(\mathrm{~m}, 1 \mathrm{H}), 0.32(\mathrm{~s}, 6 \mathrm{H})$.

Method 4b. 4-Benzoyl-4-pentenal. 4-Lithio-4-pentenal dimethyl acetal (see method 4a) was reacted with benzaldehyde at $-120^{\circ} \mathrm{C}$ and then warmed to room temperature over $20 \mathrm{~h}$. The mixture was stirred at room temperature for $3 \mathrm{~h}$ and worked up as above, yielding 5-hydroxy-4. methylene-5-phenylpentanal dimethyl acetal $(94 \%)$. This alcohol was oxidized by the method of Swern, ${ }^{34}$ but in the workup the organic layer was washed with $5 \%$ aqueous tartaric acid instead of $\mathrm{HCl}$ to give 4-benzoyl4-pentenal dimethyl acetal in almost quantitative yield. Acid hydrolysis by method $\mathrm{F}(4 \mathrm{~h}$ ) followed by distillation and flash chromatography (silica gel, 20\% ethyl acetate/hexane) gave 4-benzoyl-4-pentenal as a pale yellow oil: $51 \%$ yield (based on 4-bromo-4-pentenal dimethyl acetal); bp 84-87 ${ }^{\circ} \mathrm{C}(0.4 \mathrm{mmHg}) ;{ }^{1} \mathrm{H}$ NMR $\left(500 \mathrm{MHz}, \mathrm{CDCl}_{3}\right) 89.76(\mathrm{~s}, 1 \mathrm{H})$, $7.67(\mathrm{~d}, J=7.8 \mathrm{~Hz}, 2 \mathrm{H}), 7.50(\mathrm{t}, J=7.4 \mathrm{~Hz}, 1 \mathrm{H}), 7.39-7.37(\mathrm{~m}, 2$ $\mathrm{H}), 5.89(\mathrm{~s}, 1 \mathrm{H}), 5.66(\mathrm{~s}, 1 \mathrm{H}), 2.79(\mathrm{t}, J=7.2 \mathrm{~Hz}, 2 \mathrm{H}), 2.70(\mathrm{t}, J=$ $7.2 \mathrm{~Hz}, 2 \mathrm{H})$. Cyclopentanone product: ${ }^{1} \mathrm{H}$ NMR $\left(500 \mathrm{MHz}, \mathrm{CDCl}_{3}\right)$ 8 7.97-7.94 (m, $2 \mathrm{H}), 7.59-7.54(\mathrm{~m}, 1 \mathrm{H}), 7.50-7.43(\mathrm{~m}, 2 \mathrm{H}), 4.16-4.06$ (m, $1 \mathrm{H}), 2.74-2.66(\mathrm{~m}, 1 \mathrm{H}), 2.49-2.23(\mathrm{~m}, 4 \mathrm{H}), 2.21-2.13(\mathrm{~m}, 1 \mathrm{H})$.

4-Acetyl-4-pentenal. This compound was similarly prepared from acetaldehyde. The 4-acetyl-4-pentenal dimethyl acetal was purified by distillation (bp $67-68^{\circ} \mathrm{C}(0.4 \mathrm{mmHg})$ ) before hydrolysis by method $\mathrm{D}$ $(5 \mathrm{~h})$. The product was purified by two distillations followed by flash chromatography (silica gel, $40 \%$ ethyl acetate/ hexane), giving a colorless oil: $30 \%$ yield (based on 4-bromo-4-pentenal dimethyl acetal); bp 35-36 ${ }^{\circ} \mathrm{C}(0.4 \mathrm{mmHz}), 74-76^{\circ} \mathrm{C}(4 \mathrm{mmHg}) ;{ }^{1} \mathrm{H} \mathrm{NMR}\left(400 \mathrm{MHz}^{\circ} \mathrm{CDCl}_{3}\right)$ $\delta 9.69(\mathrm{~s}, 1 \mathrm{H}), 6.03(\mathrm{~s}, 1 \mathrm{H}), 5.83(\mathrm{~s}, 1 \mathrm{H}), 2.58(\mathrm{~s}, 4 \mathrm{H}), 2.33(\mathrm{~s}, 3 \mathrm{H})$. Cyclopentanone product: ${ }^{1} \mathrm{H}$ NMR $\left(400 \mathrm{MHz}, \mathrm{CDCl}_{3}\right) \delta 3.31-3.23$ (m, $1 \mathrm{H}), 2.55-2.46(\mathrm{~m}, 1 \mathrm{H}), 2.42-2.18(\mathrm{~m}, 4 \mathrm{H}), 2.26(\mathrm{~s}, 3 \mathrm{H}), 2.07-1.95$ $(\mathrm{m}, 1 \mathrm{H})$

(34) Omura, K.; Swern, D. Tetrahedron 1978, 34, 1651 
4-(2,2-Dimethylpropionoyl)-4-pentenal. This compound was similarly prepared from 2,2-dimethylpropionaldehyde and hydrolyzed by method $D(5 \mathrm{~h})$. It was purified by distillation followed by flash chromatography (silica gel, $25 \%$ ethyl acetate/hexane) giving a colorless oil: $45 \%$ yield (based on 4-bromo-4-pentenal dimethyl acetal); bp $58^{\circ} \mathrm{C}(0.4 \mathrm{mmHg})$; iH NMR (300 MHz, $\left.\mathrm{CDCl}_{3}\right) \delta 9.77(\mathrm{~s}, 1 \mathrm{H}), 5.55(\mathrm{~s}, 1 \mathrm{H}), 5.48(\mathrm{~s}, 1$ $\mathrm{H}), 2.60(\mathrm{~s}, 4 \mathrm{H}), 1.25(\mathrm{~s}, 9 \mathrm{H})$. Cyclopentanone product: ${ }^{1} \mathrm{H}$ NMR $\left(400 \mathrm{MHz}, \mathrm{CDCl}_{3}\right) \delta 3.68-3.59(\mathrm{~m}, 1 \mathrm{H}), 2.50-2.37(\mathrm{~m}, 2 \mathrm{H}), 2.33-2.12$ $(\mathrm{m}, 3 \mathrm{H}), 2.06-1.94(\mathrm{~m}, 1 \mathrm{H}), 1.19(\mathrm{~s}, 9 \mathrm{H})$.

Method 4c. 4-(1-Methoxycyclopentyl)-4-pentenal. 4-Lithio-4-pentenal dimethyl acetal (see method 4a) was reacted with cyclopentanone at $-120^{\circ} \mathrm{C}$ and then warmed to room temperature over $20 \mathrm{~h}$. The mixture was stirred at room temperature for $3 \mathrm{~h}$ and worked up as above to yield after flash chromatography (silica gel, $30 \%$ ethyl acetate/hexane) 1-cyclopentyl-5,5-dimethoxy-2-methylene-1-pentanol in 55\% yield. This alcohol $(2.70 \mathrm{~g}, 12.6 \mathrm{mmol})$ in dry DMF $(7.0 \mathrm{~mL})$ was added to a stirring suspension of $\mathrm{NaH}(0.59 \mathrm{~g}, 80 \%$ dispersion in mineral oil, $20.5 \mathrm{mmol}$, freed from mineral oil by hexane washes $(3 \times 15 \mathrm{~mL}))$ in dry DMF $(10.0$ $\mathrm{mL}$ ), and the mixture was stirred at room temperature for $3 \mathrm{~h}$ under nitrogen. Methyl iodide $(2.35 \mathrm{~mL}, 37.8 \mathrm{mmol})$ was added dropwise, and the reaction was stirred for $18 \mathrm{~h}$. The reaction mixture was diluted with hexane $(200 \mathrm{~mL})$ and then poured into brine $(100 \mathrm{~mL}$, saturated with $\left.\mathrm{NaHCO}_{3}\right)$. The aqueous layer was extracted with hexane $(2 \times 100 \mathrm{~mL})$ The combined organic layers were washed with brine $(3 \times 100 \mathrm{~mL}$, saturated with $\left.\mathrm{NaHCO}_{3}\right)$ and dried $\left(\mathrm{Na}_{2} \mathrm{SO}_{4}\right)$. Filtration and removal of solvents under reduced pressure gave the crude acetal, $2.92 \mathrm{~g}$, a yellow oil, which was hydrolyzed by method E (110 h) to give 4-(1-methoxycyclopentyl)-4-pentenal. The product was purified by flash chromatography (silica gel, $25 \%$ ethyl acetate/hexane) followed by distillation, giving a colorless oil: $1.41 \mathrm{~g}, 34 \%$ yield (based on 4-bromo-4-pentenal dimethyl acetal); bp 54-55 ${ }^{\circ} \mathrm{C}(0.4 \mathrm{mmHg}) ;{ }^{1} \mathrm{H} \mathrm{NMR}\left(300 \mathrm{MHz}, \mathrm{CDCl}_{3}\right)$ $\delta 9.84(\mathrm{~s}, 1 \mathrm{H}), 5.05(\mathrm{~s}, 1 \mathrm{H}), 4.90(\mathrm{~s}, 1 \mathrm{H}), 3.00(\mathrm{~s}, 3 \mathrm{H}), 2.7-2.6(\mathrm{~m}$, $2 \mathrm{H}), 2.5-2.4(\mathrm{~m}, 2 \mathrm{H}), 2.0-1.6(\mathrm{~m}, 8 \mathrm{H})$. Cyclopentanone product: ${ }^{1} \mathrm{H}$ NMR $\left(500 \mathrm{MHz}, \mathrm{CDCl}_{3}\right) \delta 3.17(\mathrm{~s}, 3 \mathrm{H}), 2.62-2.54(\mathrm{~m}, 1 \mathrm{H}), 2.38-2.31$ $(\mathrm{m}, 1 \mathrm{H}), 2.30-2.23(\mathrm{~m}, 1 \mathrm{H}), 2.21-1.99(\mathrm{~m} 3 \mathrm{H}), 1.83-1.67(\mathrm{~m}, 6 \mathrm{H})$, 1.61-1.47 (m, $3 \mathrm{H})$.

4-(1-Methoxy-1-methylethyl)-4-pentenal. Acetone was reacted with 4-lithio-4-pentenal dimethyl acetal to yield 4-(1-hydroxy-1-methylethyl)4-pentenal dimethyl acetal. O-Methylation (DMF/NaH as above) and hydrolysis by method $E(100 \mathrm{~h})$ gave 4-(1-methoxy-1-methylethyl)-4pentenal. The product was purified by flash chromatography (silica gel, $30 \%$ ethyl acetate/hexane) followed by distillation, giving a colorless oil: $30 \%$ yield (based on 4-bromo-4-pentenal dimethyl acetal); bp $34-35^{\circ} \mathrm{C}$ $(0.4 \mathrm{mmHg}) ;{ }^{1} \mathrm{H}$ NMR $\left(500 \mathrm{MHz}, \mathrm{CDCl}_{3}\right) \delta 9.74(\mathrm{~s}, 1 \mathrm{H}), 5.04(\mathrm{~s}, 1$ $\mathrm{H}), 4.85(\mathrm{~s}, 1 \mathrm{H}), 3.05(\mathrm{~s}, 3 \mathrm{H}), 2.62(\mathrm{t}, J=7.5 \mathrm{~Hz}, 2 \mathrm{H}), 2.42(\mathrm{t}, J=$ $7.5 \mathrm{~Hz}, 2 \mathrm{H}), 1.31(\mathrm{~s}, 6 \mathrm{H})$. Cyclopentanone product: ' $\mathrm{H}$ NMR ( 500 $\left.\mathrm{MHz}, \mathrm{CDCl}_{3}\right) \delta 3.19(\mathrm{~s}, 3 \mathrm{H}), 2.33-2.10(\mathrm{~m}, 5 \mathrm{H}), 2.13-1.96(\mathrm{~m}, 1 \mathrm{H})$, $1.86-1.77(\mathrm{~m}, 1 \mathrm{H}), 1.15(\mathrm{~d}, J=6.5 \mathrm{~Hz}, 6 \mathrm{H})$

1-Deuterio-4-(1,1-Dimethylethyl)-4-pentenal $d_{1}$. 1,1-Dimethylethyl 4-(1,1-dimethylethyl)-4-pentenoate was prepared from 3,3-dimethyl-2(bromomethyl)-1-butene ${ }^{35}$ and the lithium salt of tert-butyl acetate by the method of Schlessinger ${ }^{36}$ ( $65 \%$ yield). The ester was reduced in $\mathrm{Et}_{2} \mathrm{O}$ with LiAID 4 , yielding the dideuterated alcohol ( $94 \%$ yield). This alcohol was oxidized with pyridiniodichromate by the method of Corey ${ }^{37}$ and purified by flash chromatography (silica gel, $8 \%$ ethyl acetate/hexane), givine 1-deuterio-4-(1,1-dimethylethyl)-4-pentenal- $d_{1}$ as a colorless oil: $25 \%$ yield; ' $\mathrm{H}$ NMR ( $\left.300 \mathrm{MHz}, \mathrm{CDCl}_{3}\right) \delta 4.92(\mathrm{~s}, 1 \mathrm{H}), 4.62(\mathrm{~s}, 1 \mathrm{H})$, 2.64-2.59 $(\mathrm{m}, 2 \mathrm{H}) 2.43-2.38(\mathrm{~m}, 2 \mathrm{H})$. The protio form of the aldehyde could be detected by ${ }^{1} \mathrm{H}$ NMR but was $<1 \%$. Cyclopentanone product: ${ }^{1} \mathrm{H}$ NMR $\left(400 \mathrm{MHz}, \mathrm{C}_{6} \mathrm{D}_{6}\right) \delta 2.01-1.92(\mathrm{~m}, 1 \mathrm{H}), 1.92-1.84(\mathrm{~m}, 1 \mathrm{H})$, $1.77-1.65(\mathrm{~m}, 1 \mathrm{H}), 1.56-1.48(\mathrm{~m}, 1 \mathrm{H}), 1.41-1.33(\mathrm{~m}, 1 \mathrm{H}), 1.02-0.88$ $(\mathrm{m}, 1 \mathrm{H}), 0.61(\mathrm{~s}, 9 \mathrm{H})$.

(35) DeDeyne, R.; Anteunis, J. O. Bull. Soc. Chim. Belg. 1976, 85, 319 (36) Cregge, R. J.; Herrmann, J. L.; Lee, C.S.; Richman, J. E.; Schlessinger, R. H. Tetrahedron Lett. 1973, 2425 .

(37) Corey, E. J.; Schmidt, G. Tetrahedron Lett. 1979, 399.

(38) Eisenbraun, E. J.; McElvain, S. M. J. Am. Chem. Soc. 1955, 77, 3383.

(39) Posner, G. H.; Frye, L. L.; Hulce, M. Tetrahedron 1984, 40, 1401 (40) Taber, D. F.; Raman, K. J. Am. Chem. Soc. 1983, 105, 5935. Posner G. H.; Hulce, M. Tetrahedron Lett. 1984, 25, 379.

(41) Toki, K. Bull. Chem. Soc. Jpn. 1958, 31, 333. Hill, R. K.; Foley, P. J., Jr.; Gardella, L. A. J. Org. Chem. 1967, 32, 2330 and references cited therein.

(42) Trigalo, F.; Buisson, D.; Azerad, R. Tetrahedron Lett. 1988, 29,6109.

(43) Paquette, L. A.; Maynard, G. D.; Ra, C. S.; Hope, M. J. Org. Chem $1989,54,1408$
General Procedure for Small-Scale Catalytic Reactions. Typically, $[\mathrm{Rh}((\mathrm{S}, \mathrm{S}) \text {-chiraphos })]_{2}\left(\mathrm{ClO}_{4}\right)_{2}\left(1.96 \mathrm{mg}, 3.12 \times 10^{-6} \mathrm{~mol} \mathrm{of} \mathrm{Rh}\right)$ was weighed into an NMR tube, which was then capped with a rubber septum. The tube was flushed with argon for at least $60 \mathrm{~s}$, and then $0.5 \mathrm{~mL}$ of solvent $\left(\mathrm{CD}_{2} \mathrm{Cl}_{2}\right.$ or acetone- $\left.d_{6}\right)$ was added. Argon was slowly bubbled through the solution for $2 \mathrm{~min}$, and then the 4-pentenal substrate (7.82 $\times 10^{-5} \mathrm{~mol}$ ) was added by syringe. The reactions were monitored by ${ }^{1} \mathrm{H}$ NMR spectroscopy.

The catalyst precursor $\left[\mathrm{Rh}((S)\right.$-binap)(NBD) $] \mathrm{ClO}_{4}$ was converted to $\left[\mathrm{Rh}((S) \text {-binap)(solvent) })_{2}\right] \mathrm{ClO}_{4}$ prior to the introduction of substrate as follows. $\left[\mathrm{Rh}\left((S)\right.\right.$-binap)(NBD)]ClO $4\left(2.87 \mathrm{mg}, 3.13 \times 10^{-6} \mathrm{~mol}\right)$ was weighed into an NMR tube, which was then capped with a rubber septum. The tube was flushed with argon for at least $60 \mathrm{~s}$, and then solvent $\left(\mathrm{CD}_{2}\right.$ $\mathrm{Cl}_{2}$ or acetone- $d_{6}$ ) was added by syringe. Argon was slowly bubbled through the solution for $2 \mathrm{~min}$. The hydrogen gas was then bubbled through the solution for $2 \mathrm{~min}$, causing a color change from orangeyellow to red-orange. Argon was bubbled through the solution for $2 \mathrm{~min}$ to purge any hydrogen gas. The 4-pentenal substrate $\left(7.82 \times 10^{-5} \mathrm{~mol}\right)$ was then added by syringe. The reactions were monitored by ${ }^{1} \mathrm{H}$ NMR spectroscopy.

General Procedure for Large-Scale Catalytic Reactions. The smallscale reactions were scaled up by a factor of 6 with a few modifications. The dry, nondeuterated solvents were degassed immediately prior to use by having argon bubbled through them for at least $5 \mathrm{~min}$. Hydrogen was bubbled through the $[\mathrm{Rh}((S)$-binap)(NBD)]ClO, solution for $5 \mathrm{~min}$, and then the solution was stirred for $15 \mathrm{~min}$ before the argon was bubbled through it for $5 \mathrm{~min}$ to purge any hydrogen gas. To insure complete reaction, the large-scale reactions were run for twice the time that the small-scale reactions needed to reach completion. The solvent was removed at room temperature under reduced pressure $(15 \mathrm{mmHg})$. The residue was freed of catalyst by being dissolved in a 2:1 mixture of pentane and $\mathrm{CH}_{2} \mathrm{Cl}_{2}(\sim 3 \mathrm{~mL})$ and passed through a Florisil plug $(\sim 1 \mathrm{~g})$, washing the plug with $5-10 \mathrm{~mL}$ of the solvent mixture. The solvents were again removed under reduced pressure to yield the cyclopentanones as colorless to light yellow oils. The ${ }^{1} \mathrm{H}$ NMR data for the 3-substituted cyclopentanones are given after the ${ }^{1} \mathrm{H}$ NMR data for the corresponding aldehydes.

Determination of Enantiomeric Excesses. The crude cyclopentanones were converted to the diastereomeric hydrazone derivatives using $(S)$ (-)-1-amino-2-(methoxymethyl)pyrrolidine by the method of Enders. ${ }^{18}$ The reactions were carried out at room temperature using 1.1 equiv of the pyrrolidine for all cyclopentanones except the 3-acylcyclopentanones, which were reacted with 2.5 equiv of the pyrrolidine. The hydrazone may be syn or anti with respect to the 3-substituent, which when paired to two possible enantiomers at the 3-position gives four possible diastereomers. The syn and anti isomers are formed in approximately equal amounts. The 3-acyl-substituted cyclopentanones present the possibility of forming bis-hydrazones, but 3-(2,2-dimethylpropionyl)cyclopentanone and 3-benzoylcyclopentanone formed exclusively monohydrazones at the cyclopentanone carbonyl. 3-Acetylcyclopentanone showed little or no discrimination between the two carbonyl groups, giving rise to two sets of eight imine carbon signals in the ${ }^{13} \mathrm{C}$ NMR spectra. The ees were calculated from the integrations of the diastereomeric imine carbon signals in the ${ }^{13} \mathrm{C}$ NMR spectra (Table 4). When the peaks were sufficiently separated, all four signals (or 16 in the case of 3-acetylcyclopentanone) were used to calculate the ee, summing the appropriate sets. The signal-to-noise ratio in the imine region was greater than 100:1. Absolute configuration assignments were made by measuring the optical rotation of the crude cyclopentanones, as isolated above, and comparing the sign of rotation to those of known cyclopentanones where possible (Table 5). In other cases, assignments were made on the basis of similar behavior of the diastereomeric imine carbon signals. The signals for the known $S$ enantiomer always appeared upfield from those of the $R$ enantiomer. The ees reported in Tables 1, 2, and 3 were measured by the more accurate method using ${ }^{13} \mathrm{C}$ NMR.

Acknowledgment. This work was supported by grants from the National Institutes of Health. 